\title{
The application of quantification techniques in proteomics for biomedical research.
}

Link to publication record in Manchester Research Explorer

\section{Citation for published version (APA):}

Whetton, A., \& Rodríguez-Suárez, E. (2012). The application of quantification techniques in proteomics for biomedical research. Mass spectrometry reviews, 32(1), 1-26.

\section{Published in:}

Mass spectrometry reviews

\section{Citing this paper}

Please note that where the full-text provided on Manchester Research Explorer is the Author Accepted Manuscript or Proof version this may differ from the final Published version. If citing, it is advised that you check and use the publisher's definitive version.

\section{General rights}

Copyright and moral rights for the publications made accessible in the Research Explorer are retained by the authors and/or other copyright owners and it is a condition of accessing publications that users recognise and abide by the legal requirements associated with these rights.

\section{Takedown policy}

If you believe that this document breaches copyright please refer to the University of Manchester's Takedown Procedures [http://man.ac.uk/04Y6Bo] or contact uml.scholarlycommunications@manchester.ac.uk providing relevant details, so we can investigate your claim.

\section{OPEN ACCESS}




\title{
THE APPLICATION OF OUANTIFICATION TECHNIOUES IN PROTEOMICS FOR BIOMEDICAL RESEARCH
}

\author{
Eva Rodríguez-Suárez ${ }^{\mathbf{1}}$ and Anthony D. Whetton ${ }^{\mathbf{2}}$ \\ ${ }^{1}$ Proteomic Unit, CIC bioGUNE, CIBERehd, ProteoRed, Derio, Spain \\ ${ }^{2}$ School of Cancer and Enabling Sciences, Manchester Academic Health \\ Science Centre, University of Manchester, Manchester M20 3LJ, \\ United Kingdom
}

Received 7 June 2011; revised 9 February 2012; accepted 10 February 2012

Published online 30 July 2012 in Wiley Online Library (wileyonlinelibrary.com). DOI 10.1002/mas.21347

\begin{abstract}
The systematic analysis of biological processes requires an understanding of the quantitative expression patterns of proteins, their interacting partners and their subcellular localization. This information was formerly difficult to accrue as the relative quantification of proteins relied on antibody-based methods and other approaches with low throughput. The advent of soft ionization techniques in mass spectrometry plus advances in separation technologies has aligned protein systems biology with messenger RNA, DNA, and microarray technologies to provide data on systems as opposed to singular protein entities. Another aspect of quantitative proteomics that increases its importance for the coming few years is the significant technical developments underway both for high pressure liquid chromatography and mass spectrum devices. Hence, robustness, reproducibility and mass accuracy are still improving with every new generation of instruments. Nonetheless, the methods employed require validation and comparison to design fit for purpose experiments in advanced protein analyses. This review considers the newly developed systematic protein investigation methods and their value from the standpoint that relative or absolute protein quantification is required de rigueur in biomedical research.
\end{abstract}

(C) 2012 Wiley Periodicals, Inc. Mass Spec Rev 32:1-26, 2013

Keywords: relative quantification; absolute quantification; isotopic labeling; label-free quantification; biomarker

\section{INTRODUCTION}

The identification and quantification of expressed proteins in cells, tissue and whole organisms, is one of the greatest challenges in the post-genomic era. The complete genomic sequencing of humans and a variety of animals and plants has enabled this process, but methods for protein identification and sequencing, increased sensitivity of mass spectrometers for peptide identification, plus the release of new software focused on the interpretation of mass spectrometric data for the relative and absolute quantification of proteins, has fostered the opportunity to develop high throughput protein analyses. This is encapsulated in the term proteomics, which

Contract grant sponsor: Leukaemia Lymphoma Research; Contract grant sponsor: Cancer Research UK; Contract grant sponsor: CIBERehd and ProteoRed.

*Correspondence to: Eva Rodríguez-Suárez, Proteomics Unit, CIC bioGUNE, Technology Park, Bldg. 800 Derio, Bizkaia 48160, Spain. E-mail: erodriguez@cicbiogune.es is defined as the study of the proteome of a cell or tissue at a given time, where the proteome is defined as the total protein complement (Wilkins, 1996).

The most widely used mass spectrometric strategy for in-depth protein identification is called shotgun proteomics. It is based on digesting proteins into peptides and sequencing them using liquid chromatography coupled to tandem mass spectrometry (LC-MS/MS) and automated database searching (Yates et al., 1995). Search engines use the information generated by LC-MS/MS to identify peptides sequences from tandem mass spectra data. Hence, a combination of peptide intact mass and the masses of the associated fragments is used to identify peptides grouped in databases of protein sequences.

Large-scale quantitative proteomics produces a volume of data that previously would have taken decades to analyze with classical biochemical methods. There has been rapid progress in protein relative quantification in complex samples over the past two decades. Protein quantification began by comparison of the spot patterns of two-dimensional polyacrylamide gel electrophoresis (2D-PAGE). The use of dyes to stain and thereby relatively quantify protein-containing spots was an absolute requirement. Dyes such as Coomassie Blue offered very limited dynamic range of detection (approximately $1 \mathrm{log}$ ). The use of fluorescent staining overcame both this issue and the lower sensitivity of Coomassie Blue (Hart et al., 2003; Martin et al., 2003; Steinberg et al., 2003; Ge et al., 2004). Fluorescent two-dimensional differential gel electrophoresis (2D-DIGE) allows the derivatization of two different protein mixture samples with fluorophores, which could then be mixed and then run on a single $2 \mathrm{D}$-gel. Then, the $2 \mathrm{DE}$ is imaged using different excitation and emission wavelengths, and the different images obtained can be used to quantify the protein changes from sample to sample (Ünlü et al., 1997; Rabilloud, 2002; Alban et al., 2003). The possibility of running two different samples on the same gel minimizes the problem of reproducibility from gel to gel reducing also the number of gels that must be run to make comparisons between samples. However, many proteins such as hydrophobic membrane proteins or low abundance proteins, fail to be detected by 2D-PAGE and one protein spot can contain more than one protein. On the other hand, post-translationally modified proteins can be separated into their different forms on 2D gels, as can proteolyzed proteins. This offers opportunities some of the gel-free methods below do not in terms of discovering new regulatory events in biosystems (Boumahrou et al., 2011; Leung et al., 2011; Pitarch et al., 2011; Yu et al., 2011). 
In the last decade, most of the proteomic quantification studies have moved from 2D-PAGE technology to gel-free quantification approaches. Obtaining accurate quantification of protein profiles is an essential element in these proteomic analyses (Rifai et al., 2006; Conrad et al., 2008; Choi et al., 2010; Qualtieri et al., 2010; Richardson et al., 2010; Schwamborn et al., 2010; Tjalsma, 2010). Equally important in this process of quantification is rigorous methods for sample replication to generate accuracy and precision. Related to this is the limitation imposed by sample analyte dynamic range. A dynamic range of $10^{6}$ for the proteins present in a human cell line offers great challenges for the measurement and quantification of low abundance proteins (Corthals et al., 2000). This situation can be even worse in biofluids in which proteins such as albumin can impose a dynamic range of approximately $10^{10}$ (Anderson \& Anderson, 2002). This range issue cannot be overcome by any of the existing quantification techniques demanding sample fractionation and/or enrichment for specific proteins or a subset of proteins. In fact, it has been described that the electrospray ionization (ESI) approach, the most widely used ionization technique to link the chromatographic phase to the spectrometric phase, has a dynamic range of 3-4 orders of magnitude limited by ion suppression (Zook \& Bruins, 1997; Tang et al., 2004). For that reason, there are experimental approaches for sample pre-fractionation or proteome fractionation.

The review will therefore consider the sample as a complex mixture, and how this affects accurate determination of protein relative and absolute quantification. We will also consider the methods presently available for relative and absolute quantification on multiple proteins to derive systematically information on biomedical or biological material. It goes without saying that each approach has its strengths and weaknesses, which will be highlighted within the course of this review.

\section{PROCESSING BIOLOGICAL MATERIAL TO ENABLE PROTEIN RELATIVE QUANTIFICATION}

Shotgun proteomics is the most common strategy to overcome relative and absolute protein quantification by proteomic approaches. As this method relies on protein digestion, the sample complexity can become exceedingly large and it is crucial to prepare the samples in a reproducible and uniform fashion to make the quantification process comparable across different samples and different experiments. The preparation of a sample for performing quantification shotgun based proteomics covers four important steps: protein level fractionation, sample preparation, sample digestion, and peptide level fractionation which will be briefly discussed in this section.

\section{A. Protein Level Fractionation}

Prior to the relative quantification of proteomic samples, the tissue or biofluid must be lysed, fractionated and digested preceding mass spectrometry analysis as shown in Figure 1. This is in part because even the "fastest" and most sensitive mass spectrometers, which can acquire several tandem MS within a second, are overwhelmed by the number of peptides, present in a sample derived from a complex organism. Therefore, without protein fractionation, only a portion of the proteins present (high abundance proteins) would be identified per analysis (Aebersold, 2003). Hence, a way to deal with this dynamic range issue, is to fractionate the sample prior to digestion, focusing the study on a particular organelle (Jiang et al., 2005; Foster et al., 2006; Gilchrist et al., 2006; Ying et al., 2006), or on a subset of proteins of interest which share an specific post-translational modification such as phosphorylation (Dephoure et al., 2008; Lee et al., 2010) or ubiquitination (Shirran \& Botting, 2010; Xu et al., 2010; Shi et al., 2011), or on a common substrate (Hemming et al., 2009). Thus, in plasma proteomics, depletion of highly abundant proteins is one of the most effective and commonly used strategies to enhance the detection sensitivity of low abundance proteins (Anderson \& Hunter, 2006; Keshishian et al., 2007; Kuhn et al., 2009).

\section{B. Sample Preparation}

Sample preparation is a critical step in a proteomics study and can significantly influence the overall sensitivity of the analysis for a given mass spectrometric platform. Hence, the importance of sample preparation has been underlie in the development of new generation surfactants (Chen et al., 2007). Also, a "universal sample preparation method for proteome analysis" named filter-aided sample preparation method (FASP) has also been developed. FASP allows the solubilization of the proteins in SDS followed by urea exchange on a

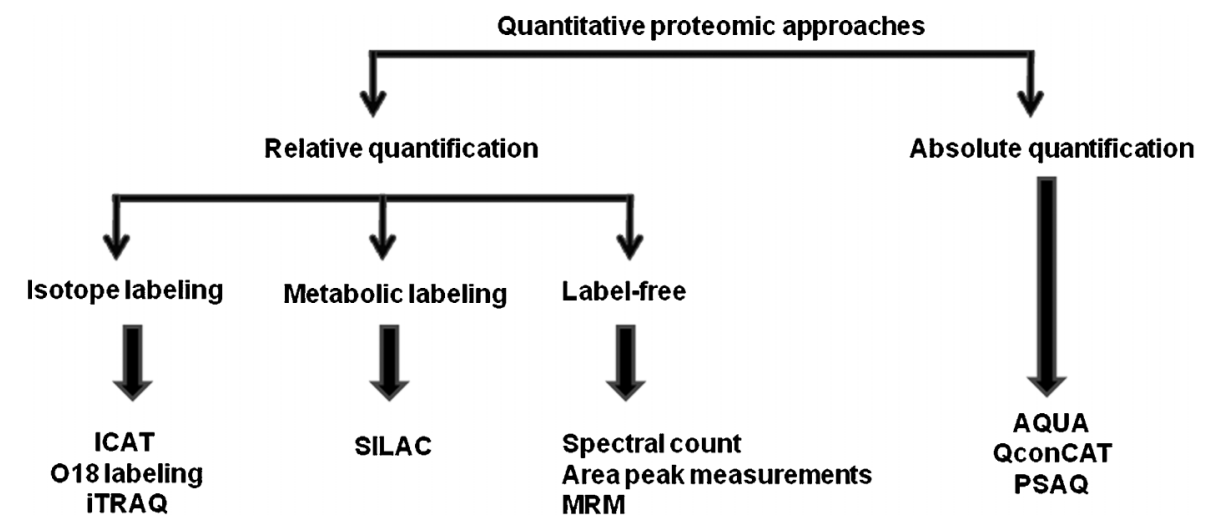

FIGURE 1. Scheme of the principal quantitative proteomic approaches. 
standard filter device allowing deeper proteome coverage, again with the aim of identifying and relatively quantifying low abundance proteins (Wiśniewski et al., 2009, 2010).

\section{Sample Digestion}

As it has been pointed out before, shotgun proteomics is the core proteomics method used today. Although other proteases have been used in proteomics experiments to increase the coverage of the proteome such as Lys-C, Lys-N, or pepsin (Raijmakers et al., 2010; Taouatas et al., 2010; López-Ferrer et al., 2011; Walther \& Mann, 2011), trypsin is the enzyme used in the vast majority of the proteomic studies due to its high substrate cleavage site specificity and also the result of the digestion of proteins with this protease is a pool of peptides with basic sites at both the $\mathrm{N}$ - and $\mathrm{C}$-termini. This increases the efficiency of the ionization process. Also, different digestion protocols have been optimized to increase the effectiveness and reproducibility of the enzymatic reaction such mixtures of organic solvents and water (Russell et al., 2001; Strader et al., 2005), sonication or application of pressure to the sample during the proteolytic process (Carreira et al., 2008; Lee et al., 2011). In addition, the combination of multiple endoproteases in the same proteome analysis is a good strategy to deepen the proteome coverage due to the complementarily of the different enzymes which renders different peptides likely to be identified (Gauci et al., 2009; Helbig et al., 2010).

\section{Peptide Level Fractionation}

As previously mentioned, the reduction of sample complexity is essential in proteomics as the high abundance proteins can mask detection of the lower abundant proteins. To circumvent these limitations preparative peptide chromatography prior to LC-MS/MS analysis is the most widespread proteomic fractionation method. Peptide strong cation exchange (SCX), 2D reversed phase-reversed phase (RP-RP) chromatography or hydrophilic interaction chromatography (HILIC) helps to reduce sample complexity, and to increase dramatically proteome coverage (Alpert, 1990; Chalkley et al., 2005; Gilar et al., 2005; Lau et al., 2011). Furthermore, the combination of consecutive chromatographic steps to simplify sample complexity has been termed multidimensional protein identification technology (MudPIT) (Washburn et al., 2001). Another fractionation approach takes advantage of the atypical presence of some amino acids. Hence, cysteine is a rare amino acid but it is present in more than $90 \%$ of human proteins and its presence can constitute an advantage to simplify protein samples using methods like diagonal chromatography (Miseta \& Csutora, 2000). Gevaert et al. developed a method to isolate sets of representative peptides with combined fractional-diagonal chromatography (COFRADIC) (Gevaert et al., 2003; Sandra et al., 2007).

The method of stable isotope standards and capture by anti-peptide antibodies (SISCAPA) was developed by Anderson et al. using peptide-based antibodies to enrich targeted low abundance peptides (Anderson et al., 2004; Hoofnagle et al., 2008). Another common approach for reducing the dynamic range of a complex mixture of proteins is sample equalization (Righetti et al., 2005, 2006, 2010; Righetti \&
Boschetti, 2008). This method uses combinatorial peptide libraries to generate a complex set of bead-immobilized ligands, each of which is able to bind, with variable affinity, a small subset of proteins in the analyte.

\section{RELATIVE QUANTIFICATION TECHNIQUES}

At the turn of the century, proteomics has been increasingly applied to the relative and absolute quantification of proteins in complex samples such as cells, tissues or body fluids using a number of techniques (see Fig. 1 for examples). Here we consider those techniques in detail but in large part, the workflows are extemporizations around the procedures shown in Figure 2.

\section{A. Metabolic Labeling}

Metabolic labeling for protein relative quantification requires the incorporation of stable isotope labels during the process of cellular metabolism and during protein synthesis. Quantification via metabolic labeling circumvents sample handling reproducibility issues as samples can be mixed very early in the preparative procedure. In addition, simultaneous measurement of ion intensities for two isotopomeric peptides in the same chromatographic run eliminates variations on performance of liquid chromatography and mass spectrometry. Thus, differences in amounts of injected sample and ion-suppression effect of co-eluting peptides do not contribute to error generation. For large-scale experiments stable isotope labeling in cell culture (SILAC) allows the in vivo incorporation of specific amino acids into all proteins via growth in the appropriate isotopomeric essential amino acids for $5 / 6$ cell passages (Ong, 2002; Zhu et al., 2002). Therefore, cells are grown in media lacking one or several standard essential amino acids but supplemented with non-radioactive isotopically labeled forms of those amino acids. Whilst the assumption that stable isotope labeling does not alter the physicochemical properties of a peptide is generally valid, it has been observed that deuterated peptides show small but significant retention time differences in RP-LC compared to their non-deuterated counterparts (Zhang et al., 2001). Protein populations are mixed directly after harvesting and mass spectrometric identification is very straightforward as it is possible to distinguish between the normal and the isotopically labeled amino acid incorporation. This approach was first described for growing yeast in medium that was more than $96 \%$ enriched in ${ }^{15} \mathrm{~N}$ (Oda et al., 1999).

In the most commonly used approach for SILAC the medium contains ${ }^{13} \mathrm{C}_{6}$-arginine and ${ }^{13} \mathrm{C}_{6}$-lysine, which ensures that all tryptic products (except the $\mathrm{C}$-terminal peptide) carry at least one labeled amino acid. However, in the case of yeast and several other microorganisms, arginine interconversion to proline can be problematic; this issue can be resolved by altering experimental conditions, informatics analyses or even deleting the enzymes necessary for amino acid conversion (Ong et al., 2003; Gruhler, 2005; Van Hoof et al., 2007; Bicho et al., 2010). In addition, by the time of planning the experiment it is worth to remember that without a complete labeling, the comparative analysis will bias the expression ratios. In principle, any of the 20 amino acids could be used as tag for labeling proteins but, of course, essential amino acids are the 


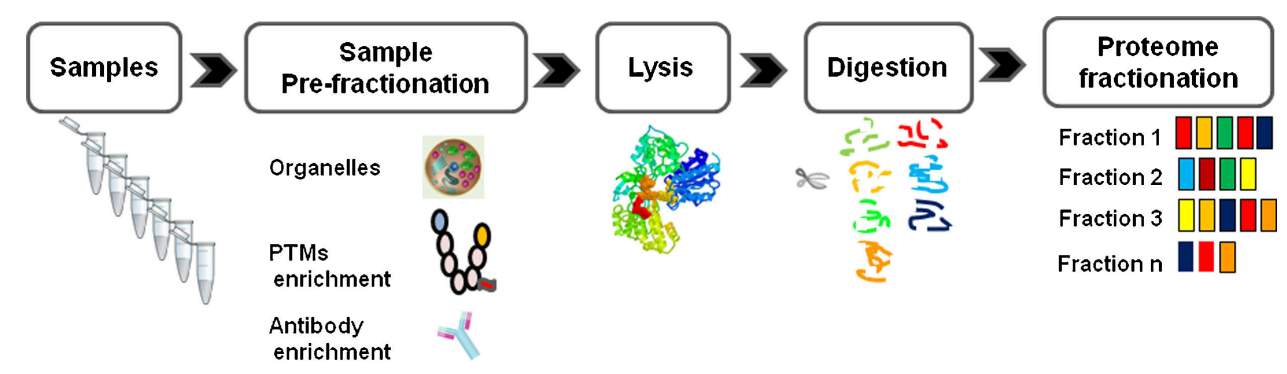

FIGURE 2. Sample preparation in proteomics. The complexity of the sample can be reduced before digestion (organelles purification, PTMs enrichment, antibody purification and so forth) or after digestion by simplification of the peptides mixture.
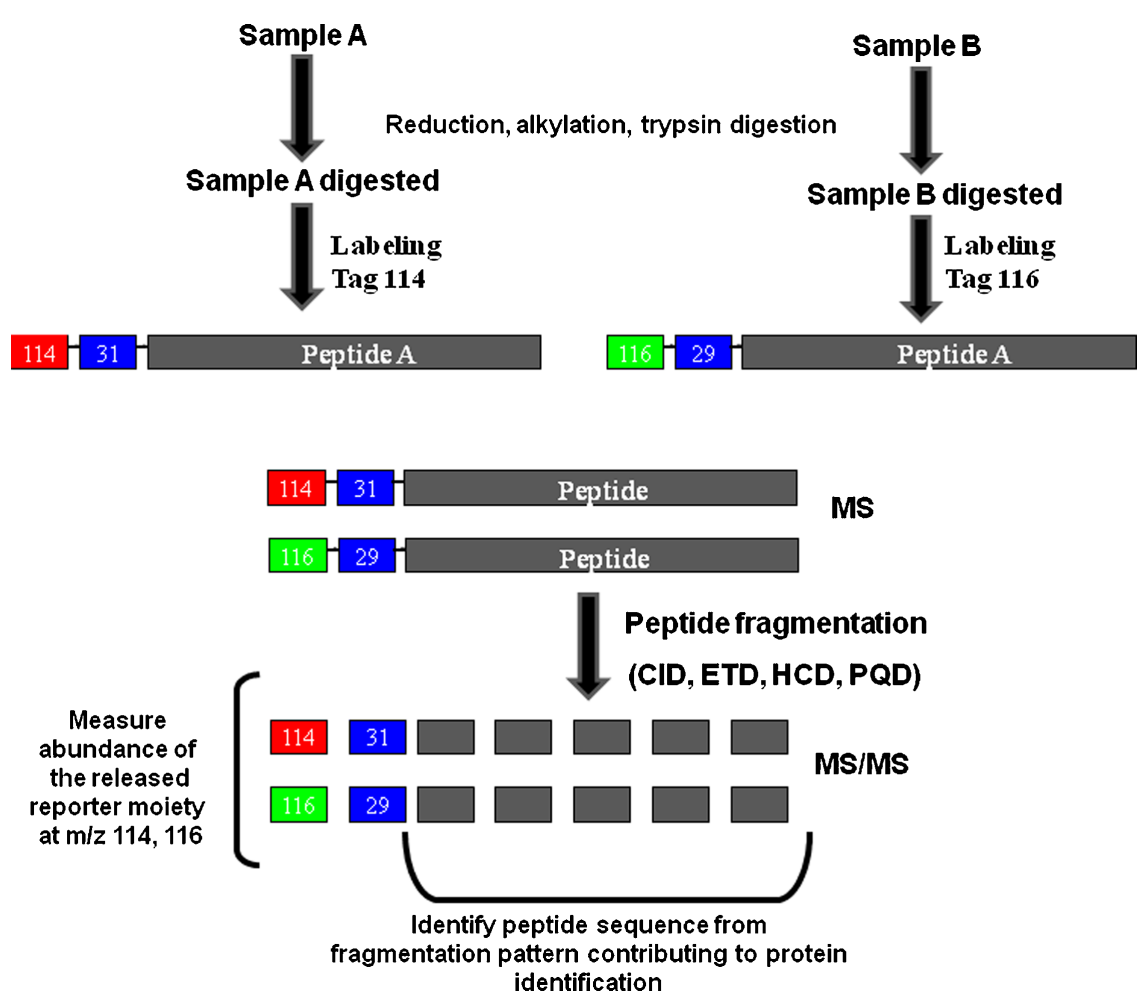

FIGURE 3. Diagram representing iTRAQ labeling in a duplex experiment. iTRAQ reagents have eight reporter moieties that allows comparison of up to eight samples in a single experiment. Sample 1 is labeled with one of the isobaric reagents $(\mathrm{m} / \mathrm{z}=114.1)$ and sample 2 is labeled with an isobaric reagent of a different $\mathrm{m} / \mathrm{z}$ (116.1). Note that the balance moieties adjacent to the isobaric reagents have the mass necessary to compensate the differences in mass of the reporter groups $(\mathrm{m} / \mathrm{z}$ is 31 and 29 respectively). The samples are mixed and subjected to mass spectrometric analysis. iTRAQ has a reporter group, a balance group and a peptide reactive group. The reporter ions have the masses 113.1, 114.11, 115.1, 116.1, 117.1, 118.1, 119.1, and 121.1 Da. The masses of the balance group ranges from 24 to 31 to ensure that the combined mass of the reporter and balance groups remains constant for all eight reagents. The isobaric tag covalently binds to the $\mathrm{N}$-terminus of lysine (Lys) side chain of peptides and enables multiplexing. Fragmentation of the tag attach to the peptides generates a low molecular mass reporter ion that is unique to the tag used to label each of the samples. Measurement of the intensity of these reporter ions enables relative quantification of the peptides and hence the proteins present in the samples. Therefore, identical peptides originating from different samples and labeled with the different reagents co-migrate in the LC-MS profile and exhibit the same parent ion in MS scans. Fragmentation is achieved by MS/MS mode in which peptides are isolated and fragmented by collision induced dissociation (CID), electron transfer dissociation (ETD), higher energy C-trap dissociation (HCD) or pulsed $\mathrm{Q}$ dissociation (PQD) which induces cleavage of both the peptide backbone and the isobaric tag. Cleavage of the peptide backbone generates different fragment ions characteristic for the peptide sequence, dissociation of the tag generates unique signature ions that distinguish the individual samples. The quantification of the proteins can be performed based on the intensity of the reporter ions. 
best option. Further consideration for the selection of the amino acid is the stability and abundance of that specific amino acid (Beynon \& Pratt, 2005). In parallel, major efforts have addressed the issue of developing bioinformatic tools to deal with the automatic processing of samples to be quantified. RelEx and MSQuant are two examples of algorithms that allow automated quantification of SILAC labeled samples (MacCoss et al., 2003; Schulze \& Mann, 2004).

Intact multicellular organisms and animal studies present additional complications where the labeling strategy has to be carefully design. Hence, proteins of Plasmodium falciparum were labeled by growing the parasite in medium containing human erythrocytes (required for their growth) and labeled isoleucine as this amino acid is not present in erythrocytes and it is an essential amino acid for the parasite (Nirmalan et al., 2004). Some successful proof of concept studies in which whole higher eukaryotic organisms were metabolically labeled have been described, these include Caenorhabditis elegans and Drosophila melanogaster (Krijgsveld et al., 2003). In 2004, the apparent metabolic labeling to near isotopomeric completion of a rat by feeding it with a protein-free diet supplemented with ${ }^{15} \mathrm{~N}$-enriched algae was achieved (Wu et al., 2004). This concept has been extended to mice to enable quantitative comparison of tissue samples from in vivo experiments (Krüger et al., 2008). Full incorporation requires feeding the animal for more than one generation, which represents the real complexity of the experiment. As in the case of individual cell types, arginine is usually avoided as the chosen SILAC amino acid because, organism labeling can result in different rates of arginine to proline conversion. Whilst the high cost of these experiments is prohibitive several studies have been reported labeling whole organisms, from bacteria to mice (de Godoy et al., 2006; Tops et al., 2009; Soufi et al., 2010; Sury et al., 2010; Walther \& Mann, 2011). These have enabled the investigators to quantitatively compare proteomes from organism under different conditions and thereby, determine protein functions under complex in vivo conditions.

Furthermore, SILAC has been extended to the study of post-translational modifications including phosphorylation (Ibarrola et al., 2003, 2004; Blagoev et al., 2004; Park et al., 2006) and in vivo methylation (Ong et al., 2004). Plainly, this has much to offer in terms of pharmacological assessments of drug action. Another application of this technique is to study the protein turnover collecting samples from cell culture or tissue at several time points after switching the growth media isomeric amino acid content to the unlabeled amino acid (Pratt et al., 2002; Doherty et al., 2005; Hayter et al., 2005). In an attempt to overcome with the restriction of the technique for working with human samples, Geiger et al. (2011) described a method coined super-SILAC based on a mix of labeled cell lines as an internal standard for tissue proteome quantification, extending the use of SILAC to cells and tissues that cannot be SILAC labeled. This approach has been demonstrated for the first time by spiking labeled neuronal cell lysates into mouse brain tissue lysates (Ishihama, 2005b). The use of classical SILAC is limited to three samples in a direct comparison but with the use of a reference or internal standard in the experimental design, there is no limit of samples that can be analyzed. However, the fact that each standard mix has to be uniquely designed and characterized for a particular sample (to cover the proteome of the tissue type under study), and that this characterization must be carried out by highly specialized laboratories with high level informatics skills makes this a workflow for interdisciplinary research of a high order. Even though, it is possible to buy labeled mouse organs from companies like Silantes $\mathrm{GmbH}$ (Munich, Germany) or Cambridge Isotope Laboratories (Andover, MA).

To summarize, SILAC has the advantage of minimal losses because no chemical labeling or affinity techniques are needed. In addition, the pooling of the samples ensures that the processing occurs in an unbiased manner and that the sample processing does not affect the final quantification. However, optimization of the protocol for growing the cells under labeling conditions is required and a handicap of this technique is that until very recently, human samples could not be analyzed. Although there has been considerable interest in stable isotope labeling in vitro, the technique is not as broadly used as chemical labeling for the reasons described above.

\section{B. Chemical Labeling}

Metabolic labeling is limited because has relied up to very recently on proteomic samples derived from cell culture. Other samples of interest in the search of biomarkers for different diseases such as tissue samples and biofluids were not amenable to this technique. Therefore, chemical labeling techniques have been and are being explored to deal with this quantification challenge.

\section{1. ${ }^{18}$ O Incorporation During Enzymatic Cleavage (Proteolytic ${ }^{18} \mathrm{O}$ Labeling)}

This quantification technique is based on the incorporation by proteolysis of two oxygen atoms from $\mathrm{H}_{2}{ }^{18} \mathrm{O}$ solvent into the C-terminal carboxyl groups of proteolytic peptides. This observation was employed for the preparation of internal standards for MS-based quantification of peptide in biological samples (Desiderio \& Kai, 1983). And latterly, it has been used for MS based relative quantification of proteomes (Mirgorodskaya, 2000). Hence, the procedure is one where a set of proteins is cleaved in "heavy" water and the other set is cleaved in "light" water. The delta $\mathrm{m} / \mathrm{z}$ after the proteolysis in these two media can be $2 \mathrm{Da}$ (single ${ }^{18} \mathrm{O}$ incorporated peptide) or $4 \mathrm{Da}$ (two ${ }^{18} \mathrm{O}$ atom incorporated peptide). However, the technique often suffers from the generation of a mixture of isotopic forms that result from the variable incorporation of either one or two ${ }^{18} \mathrm{O}$ atoms into the peptides. To achieve an accurate quantification values, correction for the isotopic contribution of the ${ }^{16} \mathrm{O}$ to the ${ }^{18} \mathrm{O}$ peptide peak is required (Rao et al., 2005). Optimal results will be achieved when proteases are employed that hydrolyze the C-termini of the peptide bond of a specific amino acid to achieve complete incorporation of two ${ }^{18} \mathrm{O}$ atoms (Miyagi \& Rao, 2007).

Several labeling protocols have been explored to circumvent the issue of incomplete labeling. Hence, combination of two enzymes, different incubation $\mathrm{pH}$ and incubation times have been thoroughly evaluated because the incorporation of two atoms of ${ }^{18} \mathrm{O}$ can change significantly by performing the reaction at acidic $\mathrm{pHs}$ or at different incubation times. Hence, Hajkova et al. (2006) found that the activity of this reaction is 17-fold higher for Lys-C than for trypsin. It is also important to note that a protease-catalyzed oxygen back-exchange 
reaction will occur when the two digests are mixed, unless the protease is completely inactivated before sample mixing (Staes et al., 2004). To help to overcome this ambiguity, a protocol with inverse ${ }^{18} \mathrm{O}$-labeling has been described (Wang et al., 2001). Significant advances in the technique were also achieved by decoupling the ${ }^{18} \mathrm{O}$ labeling from the digestion step (Yao et al., 2003) or by immobilizing the trypsin (Sevinsky et al., 2007; Mirza et al., 2008).

On a different front major efforts have been undertaken to address the issue of developing bioinformatics tools to deal with the incomplete labeling of samples to be quantified. There are several software packages that allowed interpretation of the data from ${ }^{18} \mathrm{O}$-labeling experiments in an automated fashion. Hence, Matching automatically calculates the sample ratio but it is not linked to a search engine so the identified peptides and its spectrum have to be imported before quantification (Fernández-de-Cossio et al., 2004). Halligan et al. (2005) developed a software named Zoom-Quant that quantifies data derived from an ion trap instrument (Thermo Fisher Scientific, Foster City, MA) and it is linked with the database search engine SEQUEST. Another computational tool which quantifies ${ }^{18} \mathrm{O}$ labeling samples in an automated fashion is STEM, which is linked to the database search tool Mascot (Shinkawa et al., 2005). Furthermore, algorithms to measure the ${ }^{18} \mathrm{O}$ labeling efficiency of each of the quantified peptide pairs have also been described (RamosFernández et al., 2007) as well as several models of correction for sources of variance at the scan, peptide, and protein levels (Jorge et al., 2009).

The major use of ${ }^{18} \mathrm{O}$ labeling techniques have been in comparative proteomics. The first proteomic application of this technique was for comparing two serotypes of Adenovirus (Yao et al., 2001). This labeling technique has also been used to compare proteomes of cells and tissues (Zang et al., 2004) and to analyze protein post-translation modifications such as phosphorylation (Gevaert et al., 2005; Dave et al., 2009; Lee et al., 2009).

Overall, the reproducibility of the ${ }^{18} \mathrm{O}$ labeling reaction is not simple as several parameters can modify the addition of one or two ${ }^{18} \mathrm{O}$ atoms and a standard protocol of general applicability is still lacking. Considering that the reagent needed $\left({ }^{18} \mathrm{O}\right.$-labeled water) is extremely stable and cheap, this technique is not among the most popular proteomics techniques due to two major drawbacks: first, labeling takes place late in the overall analytical process, introducing several opportunities for technical variation; second, variable incorporation of ${ }^{18} \mathrm{O}$ atoms is an important source of inaccurate assessment. Without hesitate, to overcome these drawbacks and achieve a standardize protocol for ${ }^{18} \mathrm{O}$ labeling would turn this approach in one of the gold standards of proteomic quantification.

\section{Isobaric Tags for Relative Quantification}

Isobaric tag-based methods permit simultaneous determination of both the identity and relative abundances of peptide pairs using a peptide-fragmentation-based analysis (Thompson, 2003). Tandem mass tags (TMTs) consist of a reactive group, balance and a reporter group. Peptides derivatized with TMTs are indistinguishable in the LC-MS dimension but upon fragmentation low mass MS/MS ions are generated, which can be related to the original samples prior to mixture and used for quantification (Dayon et al., 2008). iTRAQ, a further development of the TMTs, gives multiple reporter ions in a lower mass region, therefore, the reporter ions from iTRAQ have less overlap with the most intense peptide fragmentation ions; and this method is suited for relative quantification (Ross et al., 2004) (see Fig. 3 for a typical workflow). An iTRAQ labeling kit with the isobaric reagents has been commercialized by AB SCIEX Instruments and currently allows comparison of up to eight different samples (Ueda et al., 2010; Bewley et al., 2011). iTRAQ labeling is based on the same principles as TMTs and its main advantage compared with all the other quantification techniques is that up to eight samples can be analyzed simultaneously. This reduces MS analysis time, the sample amount required for the experiment and increases the confidence in peptide identification. Because the peptides with the same precursor ion but different reporter ions fragment at the same time, a higher intensity of the peptide precursor and product ions is achieved. Therefore, iTRAQ is being widely used by the scientific community for comparative protein quantification in different cell lines and tissue types. Furthermore, the fact that this method is suitable for biomedical studies makes it extremely attractive for biomarker discovery.

Despite all its advantages, it has been described that the low mass of the reporter ions makes the iTRAQ reagent incompatible with most ion traps due to these instruments' low mass cut-off. This limitation can be overcome by pulsed $\mathrm{Q}$ dissociation (PQD) or higher energy C-trap dissociation (HCD); both facilitate iTRAQ analysis on these instrument types improving the stabilization of low $\mathrm{m} / \mathrm{z}$ fragments (Griffin et al., 2007; Olsen et al., 2007). However, it has been reported that PQD suffers from poor fragmentation efficiency (Bantscheff et al., 2008). Hence, new analytical strategies have been published showing that a combination of HCD and collision activated dissociation (CAD) or HCD and CAD/ETD allow sensitive and accurate protein identification and quantification by iTRAQ labeling in ion trap instruments (Köcher et al., 2009; Mischerikow et al., 2010).

Even though quantitative applications of MALDI-TOF MS/MS present some additional challenges compared to ESI methods, numerous group have pursued analyses successfully using iTRAQ labeled samples with MALDI source employed for peptide ionization (Ruppen et al., 2010; Besson et al., 2011; Fernández-Puente et al., 2011). The reproducibility of the crystallization process matrix-analyte is not uniform across the target surface, but this handicap can be overcome acquiring and averaging many single-shot spectra from several positions within a given sample thereby gaining accuracy in the quantification (Duncan et al., 2008). Despite its handicaps, the easy of use, low cost and possibility of analyzing the sample repeatedly makes MALDI an attractive alternative as an ionization method for iTRAQ quantification. Furthermore, a recent comparison between ESI and MALDI iTRAQ quantification showed that reporter ions measured by MALDI MS/MS were more accurate than those measured by ESI-MS/MS and that by using MALDI for the ionization process, gave less underestimates of protein expression levels (Shirran \& Botting, 2010).

In addition, the appropriate analysis of data obtained for iTRAQ-labeled samples is very important; the accuracy of the quantitative values obtained is highly dependent on the 
quantitative algorithm and the statistical methods applied. The most popular software to analyze iTRAQ labeled data is Protein Pilot (AB SCIEX Instruments, Franklin, CA) but many other have been developed. Although ProQUANT software, PEAKS-Q, MASCOT, Multi-Q and i-TRACKER/TandTRACK and are often used for the quantification of iTRAQ-labeled samples, they have limitations (Shadforth et al., 2005; Lin et al., 2006; Laderas et al., 2007; Yu et al., 2007). ProQUANT is only able to handle data from AB SCIEX Instruments.

i-TRACKER/TandTRACK are limited to peptide level quantification and no protein level analysis is provided. Multi$\mathrm{Q}$ provides quantification on the peptide and protein level but does not integrate identification and quantification of the proteins in the same software package. PEAKS-Q and MASCOT have good MS/MS search engines but they do not always provide optimal quantitative iTRAQ results (Lacerda et al., 2008). The virtual expert mass spectrometry (VEMS) software (Matthiesen et al., 2005) has been updated to an integrated tool for database-dependent search of MS/MS spectra, quantification and database storage for iTRAQ labeled samples. VEMS also corrects intensity values affected by saturation and can integrate and summarize results from replica experiments (Rodríguez-Suárez et al., 2010).

Despite iTRAQ's analytical power for performing high throughput quantitative experiments and its many advantages mentioned above, iTRAQ labeling has some drawbacks that must be considered when analyzing the data derived from this quantitative approach. The main weakness for iTRAQ quantification data analysis are the impurities of specific isobaric iTRAQ reagents and also the need for a relatively high intensity of reporter ions (Bantscheff et al., 2007; Ow et al., 2010). Cross-label isotopic impurity is one of the factors liable to affect the dynamic range achievable by iTRAQ and systematically arises from manufacturer label reagents impurities and peptide co-fragmentation (D'Ascenzo et al., 2008; Savitski et al., 2010). The former is easily solved by using manufacturer-supplied correction-enabling values but the latter is more problematic. Furthermore, despite the fact that quantification in MS/MS mode should, in theory, provide a higher dynamic range, because tandem MS spectra typically exhibit less signal complexity, it has been observed that matrix contribution and co-eluting peptides significantly limit the dynamic range, increasing the exhibited heterogeneity of variance, where the variance is higher for low intensity signals (Ow et al., 2009; Burkhart et al., 2011). In addition, concerns have been raised that iTRAQ has lower accuracy when ratios tend towards one. This under-estimation has been reported across several MS platforms and has been suggested to arise from co-eluting peptides which can be selected within the ion transmission window and co-fragmented during $\mathrm{CAD}$, resulting in product ion fragmentation components that do not exclusively belong to the selected precursor (Hoopmann et al., 2007; Luethy et al., 2008). Nonetheless, to help to overcome these problems, a two component error model which stabilizes the variance for an entire dataset across the full intensity range has been developed by Karp et al. (2010).

Overall, iTRAQ is a well-established relative quantification approach, which has been widely used in comparative proteomic studies, and biomarkers search (Guo et al., 2010; Dahlhaus et al., 2011; Sela et al., 2011; VanGuilder et al., 2011; Voisin et al., 2011; Leivonen et al., 2012). As an example of multiplex studies, the 8-plex version of this approach was used to evaluate the activity of six leukemogenic tyrosine kinases and to evaluate protein expression changes in subjects subjected to immunoglobulin treatment for Alzheimer disease among others (Choe et al., 2007; Pierce et al., 2008). In general and despite its limitations and drawbacks discussed above, iTRAQ has become probably the most widespread proteomic quantification technique used by proteomics community over the last 8 years.

\section{Label-Free Quantification}

The majority of relative quantitative methods include isotopic labeling of the samples, which requires multiple sample preparation steps and can result in increased experimental variability. Label-free LC-MS quantification methods have been introduced to determine relative abundances of proteins between multiple conditions because it is argued ESI provides signal responses that correlate linearly with increasing concentration (Voyksner \& Lee, 1999; Chelius \& Bondarenko, 2002). Certain label-free LC-MS-based strategies for the global profiling of complex protein mixtures are based on spectral counting or the number of MS/MS events observed for a specific protein (Grossmann et al., 2010). The relative quantification of peptides can also be attained by direct evaluation of peak measurements (peak intensities and peak area measurements) (Bondarenko et al., 2002; Chelius \& Bondarenko, 2002). More recently, data independent exact mass LC-MS strategies have been described as an alternative to isotopically labeled and spectral counting based label-free LC-MS quantification methods (Radulovic et al., 2004; Silva et al., 2005, 2006a; Wang et al., 2006). In contrast to stable labeling methods, an obvious issue with label-free approaches based on peak intensity and area measurement is the experimental error derived by run to run variations in LC performance, amounts of injected samples and ion suppression. The advantages and disadvantages of these methods are further discussed below.

\section{Spectral Count}

Spectral count (SC), defined as the total number of spectra identified for a protein, has gained popularity as a label-free relative quantification approach. It is based on the empirical observation that the greater the molar quantity of a protein present in a sample, the more the tandem MS spectra are collected for this protein in data-dependent acquisition. Eventually, in a spike-in experiment the linear relationship across two orders of magnitude between spectral counts and protein concentration was demonstrated (Liu et al., 2004). Just prior SC was established as a relative quantification metric, Allet et al. described a similar method of estimating protein abundance based on summing the identification scores of every peptide for a given protein (Allet, 2004). Later coined as peptide match score summation (PMSS), this approach relates SC and proteins abundance weighting each peptide by its identification score (Colinge et al., 2004).

The most widespread proteomic measurement for SC is the protein abundance index (PAI). It is calculated by dividing the total number of proteolytic peptides within a protein by the observed peptides (Rappsilber et al., 2002). Peptides used for calculating PAI value are not always unique for a single 
protein (Zhang et al., 2006) hence, this index was later refined to use the number of unique peptides and to be exponentially modified PAI (giving the term emPAI) because it was shown empirically it provided the best correlation with the protein abundance within a mixture (Ishihama, 2005b). The emPAI value has also been used by commercial search engines such as those supplied by Matrix Science to give a quantification value of the proteins identified in a matrix of medium-to high complexity. Also, a free web application called EmPAI Calc calculates the emPAI from the protein identification results obtained by database search engines such as Mascot, allowing the user to modify threshold scores (Shinoda et al., 2010). These approaches have been broadly used to compare proteome profiles by many investigators. For example, the emPAI strategy was used by Beretta's group to generate a semiquantitative profile of proteins in murine liver and plasma (Lai et al., 2008), by Han et al. to evaluate pathological stages of multiple sclerosis (Han et al., 2008), by Gramolini et al. to study cardiac ventricle isolated from a mouse model of cardiomyopathy (Gramolini et al., 2008) or by de Souza et al. to describe proteomic differences between two closely related Mycobacterium tuberculosis genotype strains (de Souza et al., 2010).

In the last years, researchers have exploited the possibilities of SC as an abundance index introducing modifications to improve the accuracy of the quantification approach. Further advances have been made by using computational models, which predict the peptides of a given protein with a higher probability of being detected by the mass spectrometer and consequently used for accurate quantification. For example, the SC method termed absolute protein expression (APEX) profiling sums the probability of observing each peptide and corrects for the fact that not all the tryptic peptides are proteotypic, based on amino acid number which is argued to be directly linked to their ionization efficiency (Mallick et al., 2007). In addition, this value is multiplied by the protein's probability to give confidence in protein identification ( $\mathrm{Lu}$ et al., 2007). APEX has been released as a free-open source application termed the APEX Quantitative Proteomics Tool (Braisted et al., 2008) and was applied to study the average number of protein copies per cell in a cell population, for a large fraction of the proteome of the human pathogen Leptospira interrogan (Malmstrom et al., 2009).

$\mathrm{SC}$ has also been modified to take into consideration the number of residues in the protein under study. This variant of spectral counting is called normalized spectral abundance factor (NSAF), calculated by dividing the SC value for a protein by its length (Florens et al., 2006; Zybailov et al., 2006, 2007). This metric has been applied in the study of rat liver membrane proteins, human protein interaction networks and mouse renal cortex proteins (Chick et al., 2008; Sardiu et al., 2008; Zhao et al., 2008). A newer metric includes the fragment ion intensity to give a normalized spectral index $\left(\mathrm{SI}_{\mathrm{N}}\right)$ and has been shown to reduce variability across samples, probably due to its capacity to discern co-eluting peaks (Sardiu \& Washburn, 2010). Furthermore, a good correlation between quantification using $\mathrm{SI}_{\mathrm{N}}$ and western blot analysis has been reported in a study using lung tissue samples (Griffin et al., 2010). The method thus has application in discovering protein changes but as with all such studies, validation is required. The sensitivity and dynamic range the approach offers are, as in iTRAQ experiments and other approaches, in need of careful consideration. Systematic analysis of protein network changes between samples using this approach is feasible with caution because of its semi-quantitative nature.

Numerous studies have performed relative quantification by $\mathrm{SC}$ and these confirm that the relative quantification of the peptides can be achieved by comparison of peak intensity or peak area measurements. Hence, an interesting study by Old et al. reported that SC was more sensitive in detecting differences in expression between proteins but that peak intensity measurements were more accurate than SC measurements (Old et al., 2005). However, SC is very useful within a narrow protein dynamic range hence, once a higher protein concentration is reached and the majority of the observable peptides have been identified, the linear relationship between observed peptides and protein concentration reaches an asymptotic limit. Inevitably, this biases detection towards the most abundant proteins and raises issues of dynamic range in detection (Ghaemmaghami et al., 2003). Hence, even when the method has a strong linear correlation, SC lacks sensitivity to detect small expression differences particularly among proteins with a low spectral count value. Furthermore, for lower resolution mass spectrometers SC is said to be more accurate than ion signal intensity quantification methods (Zybailov et al., 2005), however, for higher resolution instruments a better level of performance has been described basing the analysis on intensity signals (Mueller et al., 2008). Thus, any biological experiment needs to determine its objectives and develop MS methods on preferred outcomes from their experiment.

In conclusion, SC methods break down for low abundance proteins, which are a characteristic and sizeable portion of a proteomic samples and often the protein of interest for the biomedical researchers. However, the increase in the speed for performing MS/MS events of the latest generation mass spectrometry instruments together with the development of better algorithms to identify proteotypic peptides, should improve the accuracy of spectral count measurements.

\section{Peak Measurements Quantification}

As it has been mentioned previously, it has been observed that ESI provides signal responses that correlate linearly with increasing concentration however, others have raised concerns about the non-linearity of the response (Müller et al., 2002). The premise is that ionization efficiencies and ion suppression affect the measured signal for a given peptide. A label-free approach for quantitative MS involves the integrated measurement of chromatographic peak intensities/areas for any given peptide in LC-MS runs. However, quantification on MS mode can be tricky due to problems of low intensity and saturating ions in the same MS scan. With a very low signal, it is difficult to distinguish ions from noise and at very high intensities the detector can be saturated. Hence, in trap instruments there is a software called automatic gain control used to set the ion injection time to maintain the optimum quantity of ions for each scan but in ToF instruments it is more difficult to avoid saturation (Belov et al., 2003).

As peak measurement quantification is based on the overlapping of chromatograms in different LC runs, an outstanding LC performance is crucial for the success of this label-free quantification approach. Hence, high resolution nano-LC 
systems, where temperature or pressure fluctuations have to be strictly controlled, high resolution columns, minimal dead volume connections and avoidance of column saturation are some of the precautions which should be taken to perform a high quality label-free quantification experiment. Peptides usually elute from the LC column resulting in a signal across time with a variable concentration and different charge states are frequently measured for a specific peptide, resulting in signals in different regions of the chromatogram for the same peptide. Hence, special attention must be taken with those peptides, which elute over a long period causing overlapping with coeluting peptides. Furthermore, due to technical variations, there may be fluctuations in retention time (RT) if samples to be compared are run on different columns. A further critical step is to pair or group peaks from one LC-MS profile with the same peak/peptide in other profiles. The same peptides across the different chromatograms should share the same $\mathrm{m} / \mathrm{z}$ and RT. Regular calibration of the mass spectrometer ensures that the $m / z$ fluctuation is controlled, however, the RT values are more difficult to keep consistent for any specific molecular entity. Slight variations in the age of an LC column can cause fluctuations in the RT. In addition, peptide elution peak width will increase at later elution times and for high intensity peaks will often display tailing. Thus, monitoring is required to minimize peak width as much as possible during LC-MS acquisition.

After the acquisition of the data, computational methods are required to enable time alignment, background subtraction, and intensity normalization which can account for protein loading and electrospray differences (Wang et al., 2003). The above demonstrates with hopefully some clarity the analytical challenges of this kind of study for systems biology and discovery proteomics. Beyond the MS analysis lies the generation of information from data hence, once the alignment of the chromatograms has been achieved, normalization of the data is essential for improvement of the quantitative accuracy of the experiment. Hence, abundance normalization will correct for bias due to sample loading, ionization efficiency fluctuations or carry-over. Numerous large-scale label-free quantitative proteomics studies have been performed in the last years, most of them focusing on the search of biomarkers for different diseases (Amon et al., 2010; Silvestrini et al., 2010; Cima et al., 2011; Mao et al., 2011).

One important point in label-free quantification is to achieve the right balance between acquisition of survey data and peptide fragmentation. Hence, it is necessary to have good peptide coverage to sequence a peptide from a given protein but it is also important to keep a minimum of scans on the survey to have appropriate quality ion statistics for the quantification. Due to the faster duty cycle of ion trap instruments over time of flight (ToF) instruments, the former have a higher inherent capacity for keeping a good balance between identification and quantification of proteins. An alternative approach to overcome this speed issue in ToF instruments has been proposed, in which the mass spectrometer no longer cycles between MS and MS/MS mode. This method is based on an alternate scan method between low and high collision energy, in which there is no precursor isolation and all the ions co-eluting within the same scan time are fragmented at once (Bateman et al., 2002; Nakamura et al., 2004; Niggeweg et al., 2006). The data independent acquisition method (DIA) method, also called MS-E (E for elevated energy) by Waters Corporation (MA, USA), acquires precursor and product ion data on all charge-states of an eluting peptide across its entire chromatographic peak width, providing more comprehensive precursor and product ion spectra (see Fig. 4 for an example of a peptide identification from a DIA spectrum). Moreover, with a DIA, the combination of a high-peak capacity chromatographic separation with high sampling rate orthogonal acceleration TOF mass spectrometer provides a rapid and parallel approach for generating peptide precursor and product ion detection on all eluting species across the chromatographic peak profiles. The technical variation with respect to signal intensity achieved by this approach has been shown to be 10 $15 \%$ with highly consistent reproducibility (Geromanos et al., 2009). Furthermore, the specificity afforded by the accurate mass measurements of both, the precursors and associated fragment ions provides the ability to identify with high confidence, a large number of proteins with high sequence coverage, and the ability to collect data points across the entire chromatographic peak allowing an accurate quantification of peptides and proteins recorded in accurate mass retention time (AMRT) signal responses ( $\mathrm{Li}$ et al., 2009). The clustering algorithm employed to this end utilizes the mass precision of the mass spectrometer and retention time reproducibility obtained from the chromatography to cluster the same peptides across the entire experiment. This DIA label-free quantification approach is fully automated by Protein Lynx Global Server (PLGS) (Waters), which can also perform peptide and protein identification by database search. Following the same premise, it has been described that the average MS signal responses for the three most intense tryptic peptides per mole of protein is constant with a coefficient of variation of less than $10 \%$ (Silva et al., 2006b). The method for absolute quantification of proteins requires that a known amount of protein is spiked into the sample. By comparison of the intensity of this standard with the three most intense tryptic peptides of each identified protein, a quantitative value of protein loaded onto column can be calculated. This approach has been successfully applied to the study of the nervous system development in rat, stem cells differentiation, gingival exudatome, serum of patients with Gaucher disease, reperfused myocardium, and urine samples of patients with urolithiasis among others (Vissers et al., 2007, 2009; Chambery et al., 2008; Ma et al., 2009; Bostanci et al., 2010; Wright et al., 2011).

\section{Selective Reaction Monitoring (SRM)}

Selective reaction monitoring (SRM) exploits the capabilities of triple quadrupole (QQQ) for targeted quantitative analysis. SRM is not a new technique, it has been employed over 30 years and it has been widely used in drug metabolism studies for quantification of metabolites (Gao et al., 2007; Prakash et al., 2007; Yao et al., 2008). However, the application of SRM to peptides has been adopted recently because the improvements in instrumentation makes this technique sensitive, selective and with a wide dynamic range for its application in proteomics (Domon \& Aebersold, 2006; Kuzyk et al., 2009). In SRM, the first and the third quadrupoles act as filters to select specific predefined $\mathrm{m} / \mathrm{z}$, value peptide corresponding to the precursor ion and one specific fragment ion of a selected peptide (Whiteaker et al., 2007; Nicol et al., 2008). The 

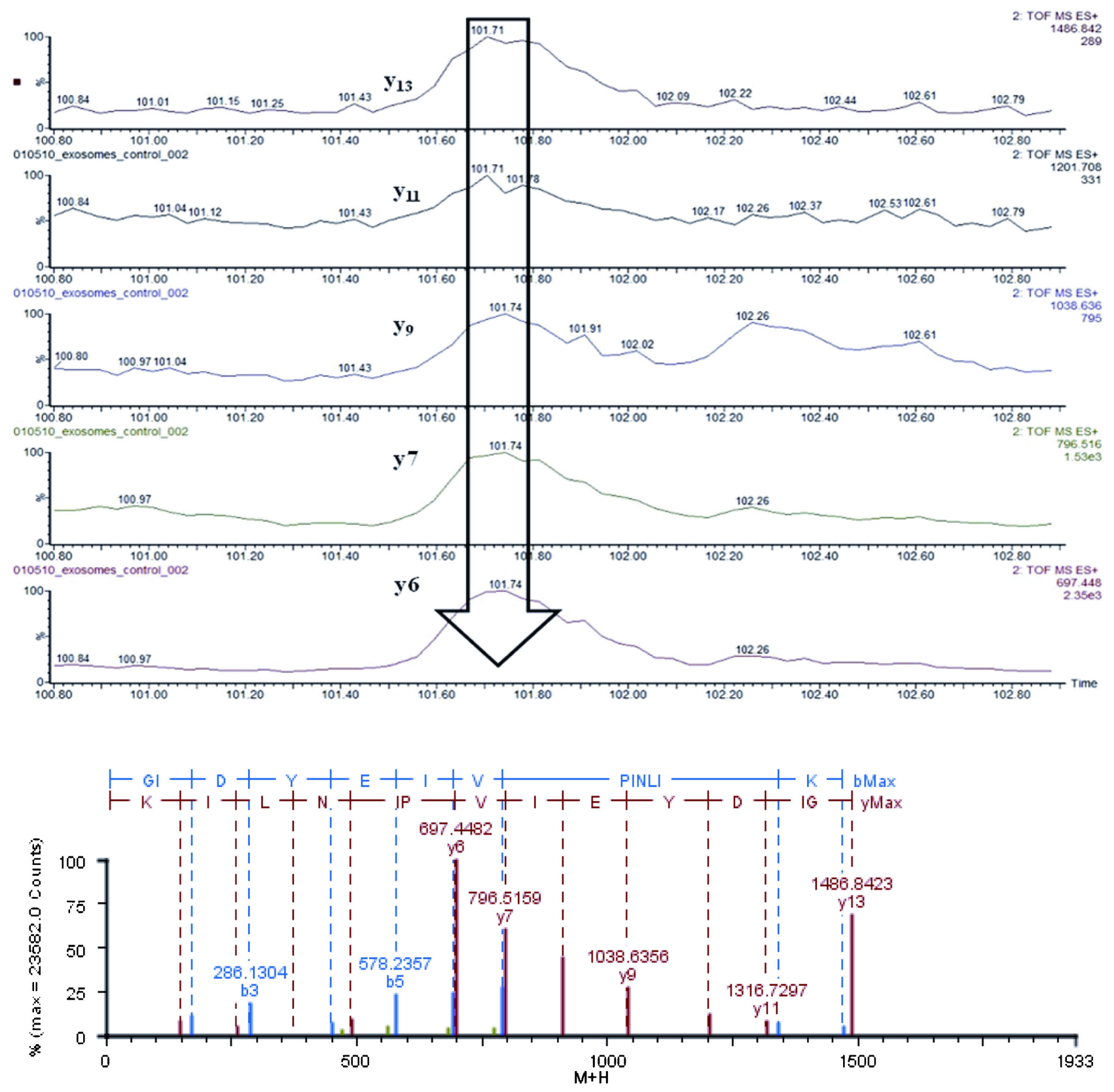

FIGURE 4. Peptide identification from an LC-DIA analysis. DIA analysis is based on an alternate scan method between low and high collision energy, in which there is no precursor isolation and all the ions co-eluting within the same scan time are fragmented at once. A: An single ion chromatogram (SIC) of the doubly charged $\mathrm{m} / \mathrm{z} 744.39$ precursor peptide ion from the low energy channel (function1) with an apex retention time of $101.71 \mathrm{~min}$ and five associated fragment ions $(\mathrm{m} / \mathrm{z}: 697.44,796.516,1038.636,1201.76,1486.83)$ from the elevated energy channel (function 2) that all chromatographically apex at 101.74. B: The timeresolved fragment ions from the doubly charged $\mathrm{m} / \mathrm{z} 744.39$ precursor peptide identified as GIDYEIVPINLIK peptide from glutathione- $S$-transferase.

combination of the $\mathrm{m} / \mathrm{z}$ values selected for the first and the third quadrupoles is known as a transition. The non-scanning set-up of this mode of operation increases sensitivity by one or two orders of magnitude and extends a linear response of quantification to 4-5 orders of magnitude (Kirkpatrick et al., 2005). There are several thoughts to take into consideration before performing a SRM experiment (reviewed by Lange et al., 2008b).

1. The proteins under study have to be selected, a subjective step requiring prior knowledge of their biological interest or potential change in levels between samples. 
2. Proteotypic peptides for each targeted protein have to be defined. As has been defined previously, proteotypic peptides are unique identifiers for one protein, not being shared by several isoforms. The direct observation of highly detectable tryptic peptides is the best way of choosing those peptides prone to be subjected to SRM analysis for obvious reasons, however, among the peptides generated by tryptic digestion only a small subset is generally observed (Kuster et al., 2005). Hence, for a number of organisms, a significant number of MS experiments have been deposited in public repositories like the PeptideAtlas (Deutsch et al., 2008), Human Proteinpedia (Kandasamy et al., 2009) or PRIDE (Martens et al., 2005). These data have also been used to train software which predict the most detectable tryptic peptides (Tang et al., 2006). These repositories are poor on example SRMs where low-level protein expression is observed (such as transcription factors). Once again it is in the nature of the biology experiment or biomedicine experiment that these are just the proteins/peptides that are of interest to the investigator.

3. Potentially modified peptides should be avoided within protein quantification experiments unless there is a particular interest in a specific modified form of the protein. It is of course essential to select transitions for the most intense fragments.

Also, before performing a SRM experiment it is worth to consider that there is a limit in the number of transitions that may be quantified with high sensitivity and accuracy in a single LC-MS analysis. In SRM, the instrument goes through a list of transitions spending a defined time, called the dwell time on each transition and to achieve high sensitivity the dwell time has to be long enough to accumulate sufficient signal. The number of transitions that can be tested in a LC-MS experiment is limited but it can be increased using the retention time of each peptide where the transitions of a specific peptide are only acquired during a time window around its elution time (Stahl-Zeng et al., 2007). The retention time of the peptides must be known experimentally or calculated by tools like SSRCalc with previous calibration of the HPLC system (Krokhin et al., 2004). As alluded to above validated transitions are stored in centralized databases, together with optimized experimental setting to be accessible to the scientific community. Hence, MRMAtlas is a publicly accessible database which cover SRM assays for over 1,500 proteins (Picotti et al., 2008).

Another issue to consider is that sample complexity associated with these analyses introduces a chance of false positives transitions (Duncan et al., 2009; Sherman et al., 2009). Thus, it is important to be able to confirm the identity of the precursor ion giving rise to a specific transition. An approach has been described in which the detection of a specific SRM event automatically triggers a full product ion scan. The acquired MS/MS spectra are then compared with the predicted peptide fragments to assure that the major MS/MS peaks are matched, confirming that the detected SRM derives from the target peptide. This approach has been named as MIDAS (MRM initiated detection and sequencing) and has proven particularly useful for protein modification profiling (Unwin et al., 2009). It has been described in a triple-quadrupole- linear ion trap hybrid instrument (QqQ-LIT) which has the advantage of being able to switch rapidly between triple quadrupole and linear ion trap modes to acquire linear in trap full-scan MS/MS confirmatory data of sensitivity equal to the SRM itself and on a time scale suited to on-line chromatography. Hence, Unwin et al. (2005) showed a 10-fold enhancement in sensitivity of phosphorylation detection comparing this approach with the standard precursor ion scanning method. The same group applied a MIDAS approach to the description of acetylated residues from bovine serum albumin (Griffiths et al., 2007). However, this method has a lower sensitivity and selectivity compared with SRM as it uses a broader mass selection window, which results in MS/MS spectra often containing signals from co-eluting peptides. Another way to verify systematically the target peptide identity is using isotopically labeled counterparts but this approach is not always practical for large-scale quantitative proteomic studies. A new data acquisition method has been described in which selected reaction monitoring is performed in two ways to simultaneously quantify and confirm the identity of the peptides (Prakash et al., 2009). After the two or three most intense transitions for a given peptide are recorded, six to eight additional transitions acquired in a data dependent mode are measured and use to generate a composite MS/MS spectrum. This spectrum together with the chromatographic elution profile of the fragment ions verified the identity of the target peptide. This switch is controlled by a software called intelligent selected reaction monitoring (iSRM) that can use the specificity of a small subset of transitions to quantify and trigger the full list for confirmation of the identity of the target peptides (Kiyonami et al., 2011).

An important requirement for biomarker discovery is the validation by orthogonal methods of the markers found by relative quantification approaches. The development of immunoassays to validate putative biomarkers is expensive and dependent upon generation of high quality protein antibodies. Because antibodies only exist for a limited number of proteins, alternative approaches are needed to validate new potential biomarkers in biofluids such as serum or urine samples. Due to its very high sensitivity a limit of quantification of below 3 amol peptide loaded on column has been reported (Wolf-Yadlin et al., 2007), SRM can bridge the gap between biomarker discovery and validation by antibody based approaches, which are costly and sometimes insufficient due to the lack of antibodies against the proteins of interest. Therefore, SRM is becoming at method of choice of biomarker validation phase (Kuhn, 2004; Janecki et al., 2007; Faca et al., 2008; Keshishian et al., 2009) although the time taken to optimize such experiments should not be underestimated. Furthermore, SRM coupled with stable isotope dilution (SID) MS has been shown to be well suited for direct quantification of proteins in plasma and it has been an important advance for biomarker validation (Barr et al., 1996; Kuhn, 2004; Bondar et al., 2007).

\section{Label-Free Quantification Software}

This section will describe software quantification packages commercially and freely available to perform quantification on samples without metabolic or chemical labeling. As has been described, SC transforms the frequency by which a peptide is 
identified into a measure for peptide abundance. Scaffold (Proteome Software, Portland, OR) can accept data from various search engines such as SEQUEST and MASCOT to perform quantification based on SC (Searle, 2010). Hence, Scaffold is, mainly, a data management program that can calculate SC values and classify proteins by functional category. On the other hand, Census is freely available software capable of quantifying labeled and label-free data (Park et al., 2008) whilst PepC is a well-established tool which performs statistical analysis on the quantification of the samples based on SC and assessing data reproducibility (Heinecke et al., 2010).

Likewise, there are numerous commercial software used for label-free quantification based on peak measurements: SIEVE (Thermo Fisher Scientific) aligns the chromatograms and identifies statistically significant differences between the peak intensities of the different samples; Progenesis LC-MS (Nonlinear Dynamics, NE, Newcastle upon Tyre, UK) aligns the chromatograms choosing one as reference standard set; multivariate analysis can also be performed by this software. Another commercially available package for intensity-based label-free quantification is DeCyder MS Differential Analysis Software, which is based on DeCyder, a widely used image analysis software tool for 2D gels analysis (Johansson et al., 2006). As it has been mentioned previously, PLGS (Waters) can perform label-free peak intensity based quantification and also perform proteins identification by data base search. Among the freely available software, SpecArray was one of the first freely available software packages for label-free protein quantification ( $\mathrm{Li}$ et al., 2005). SpecArray is supported only on Linux operating platforms and does not have the capability to process tandem MS data. MSQuant is a well-known software to analyze SILAC data but is also usable for labelfree quantification (Mortensen et al., 2009). MSInspect quantifies isotope-labeled, label-free, and SRM data (Bellew et al., 2006). One pioneering software package is the trans-proteomic pipeline (TPP), which is a collection of more than 30 tools applicable to label-free or isotopic labeling quantitative data analysis (Keller et al., 2005).

As has been discussed through this review, with recent advances in triples quadrupole instrumentation, SRM allows targeted multiplexed quantitative analysis and is a valuable tool for the validation and verification of label-free and labeled quantitative proteomic experiments. Consequently, new software requirements have emerged to deal with the design of these kind of experiments. TIQAM (targeted identification for quantitative analysis by multiple reaction monitoring) integrates proteomics data from local experiments and for the Peptide Atlas database to select the best transitions (Lange et al., 2008b). In addition, several commercial solutions have been released to support the setup of SRM assays for proteomics. These platform-specific tools include MRMPilot (AB SCIEX Instruments), SRM Workflow Software (Thermo Fisher Scientific), Verify E (Waters), and Optimizer (Agilent Technologies).

These and other software tools are available to the scientific community to deal with the challenge of label-free quantification, however, assessing the multitude of algorithms available in detail is beyond the scope of this review. For more information, reviews specific to this area have been published recently (America \& Cordewener, 2008; Vandenbogaert et al., 2008).

\section{ABSOLUTE QUANTIFICATION TECHNIQUES}

In clinical translational research, the specific and accurate quantification of selected proteins in complex biological samples remains a challenge. For some if not many proteins this can be solved by immunological techniques often requiring the development of costly but specific antibodies. Recently, efforts have been made to develop antibody arrays, however these analyses remain limited (Taussig et al., 2007). In the last years, several techniques linked to MS-based proteomics have been developed to address this problem (Ong \& Mann, 2005). These techniques include the addition of an isotopic internal standard to the sample and its further characterization by MS (Fig. 5). In the near future, such techniques may be developed to a point where they supersede immunological quantification techniques such as enzyme-linked immunosorbant assay (ELISA).

\section{A. AQUA}

The use of isotope-labeled synthetic peptides was originally described in the early 1980s (Desiderio \& Kai, 1983) but it is now becoming more broadly applied since Gerber et al. (2003) developed the AQUA technique. The AQUA strategy was introduced to assess protein expression and post-translational modification changes and relies on the use of an isotope

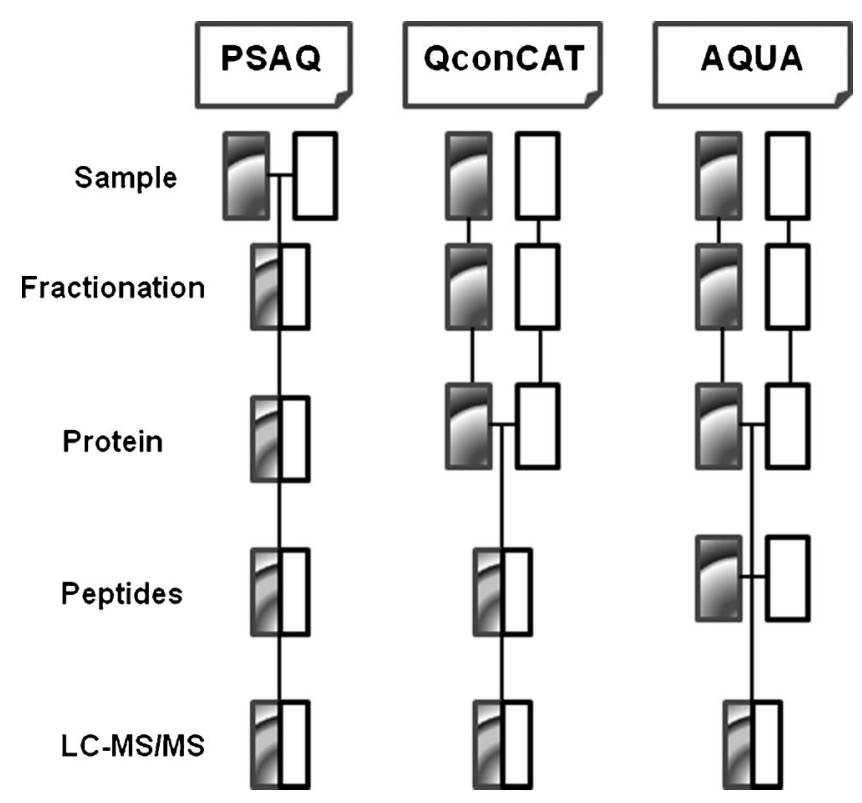

FIGURE 5. Isotope dilution strategies for targeted MS-based absolute quantification of proteins. Three types of internal standards have been described for absolute quantification of a target protein in complex samples. PSAQ (Protein Standard Absolute Quantification) is an isotope labeled version of the protein that is directly added to the sample at the beginning of the quantification procedure. The QconCAT (quantification concatamer) is a multi-chimeric protein containing proteotypic peptides of the protein of interest. It is added before the digestion step in the quantitative workflow. The AQUA peptides are synthetic isotope-labeled peptides homologous to the proteotypic peptides of the target protein, which are added to the sample just prior to LC-MS/MS analysis. Boxes in gray and white represent two experimental conditions. Horizontal lines indicated when sample are combined. Before to mix the sample experimental variation errors can occur (adapted with permission from Silva et al., 2005). 
labeled synthetic internal peptide standard that is introduced at a known concentration to cell lysates during digestion. The synthetic peptide and the native peptide share the same physicochemical properties, including chromatographic co-elution, ionization efficiency, and relative distribution of fragment ions, but are differentially detected in a mass spectrometer due to their mass difference. Since the amount of internal standard is known and the ratio between amounts of internal standard can be determined from the mass spectra, the analyte peptide can be quantified. Therefore, the quantification is performed at the peptide level rather that at the protein level. The isotope labeled AQUA peptide and the unlabeled native peptide are measured by liquid chromatography selected reaction monitoring performed in a tandem MS instrument. In the other hand, to quantify PTMs like phosphorylation, two AQUA peptides can be generated, a phosphorylated and a non-phosphorylated internal standard peptide. By comparing the amounts of the phosphorylated and non-phosphorylated versions of the peptides, the total expression of the proteins and the particular phosphorylation event can be quantified (Stemmann et al., 2001; Kirkpatrick et al., 2005).

AQUA is an absolute quantification technique that requires a knowledge of the peptide subjected to quantification and is therefore developed with prior knowledge of the biomarker protein in question or the phosphorylation event under study. Therefore, this approach is complex when applied to large number of proteins, as each standard peptide would need to be chemically synthesized in stable-isotope-labeled form and independently quantified. For this reason, proteins of interest can be quantified with a single AQUA peptide (Cheng et al., 2006). Another drawback of the AQUA approach is that since AQUA peptides are added at the latter stages of the analytical process it is poorly compatible with sample fractionation strategies. Havlis et al. used 1DE to enrich for the protein subjected to analysis performing the in-gel digestion in the presence of the AQUA peptide, which is added to the gel pieces during the digestion process. They have shown that this step compromises the technique in respect of peptide recovery efficiency from the in-gel digestion of the native peptide to be analyzed affecting the quantification accuracy of the AQUA method (Havlis \& Shevchenko, 2004). Another limitation is the specificity of the spiked standard, as there could be multiple isobaric peptides present in the mixture, and the lack of knowledge of the ionization efficiency of the proteolysis step required. Even so, the commercial availability and easy use of AQUA peptides make them particularly attractive for the researcher, as does the growing need for absolute quantification strategies to develop inter-laboratory comparative analyses of protein concentration, far less feasible with relative quantification approaches.

\section{B. Quantification Concatamer (OconCAT)}

This advanced and elegant absolute quantification technique can overcome the problem of generating relatively few synthetic peptides (allow in multiple protein quantifications to be performed). Artificial proteins that are concatamers of tryptic peptides for several proteins were designed to allow the quantification of several proteins at the same time (Fig. 6; Pratt et al., 2006). Concatamers that can be homemade or obtained commercially (PolyQuant GmbH, Regensburg, Germany) are generally added into the sample just before proteolysis and allow the parallel production of up to 50 peptides in a single experiment. The system has been firstly tested in the quantification of 20 chicken proteins identified as changing by 2DE technology in developing skeletal muscle. Unlabeled and ${ }^{15} \mathrm{~N}$-labeled QconCAT proteins were mixed in different ratios and digested with trypsin before MALDI-TOF analysis of the peptides to allow the quantification (Beynon et al., 2005). To design the QconCAT concatamers several considerations are taking into account:

1. The peptides have to be soluble allowing their isolation after production.

2. The peptide chosen has to be unique to a single protein.

3. Peptides have to ionize easily and be observable in the mass range of any spectrometer.

This approach takes advantage of identical chromatographic properties of an isotope-labeled peptide and its unlabeled equivalent in LC-MS analyses. One major advantage of

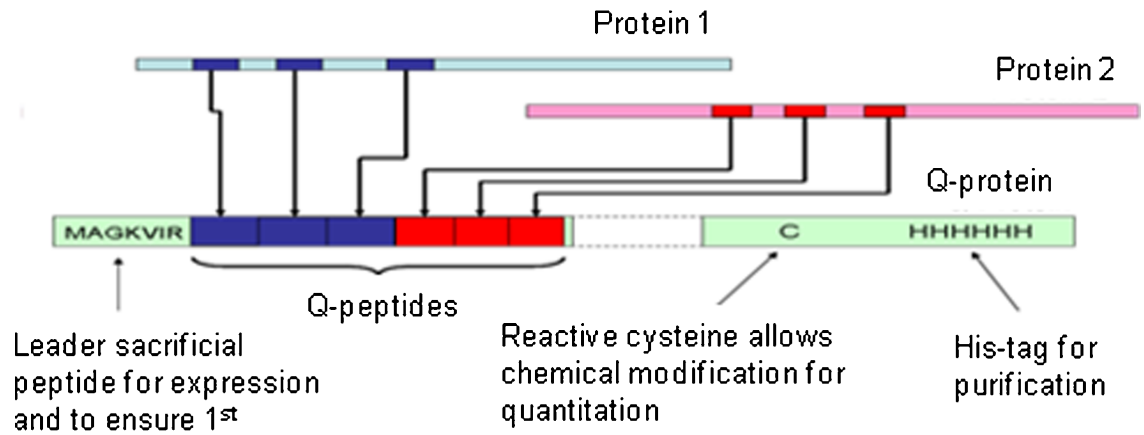

FIGURE 6. QconCAT scheme. QconCAT involves generation of a custom protein containing tryptic peptides from several (many) target proteins, providing a source of standards (of equal abundance) for absolute quantification. Peptides form target proteins are chosen for their lack of possible PTMs and theoretical ESI properties plus lack of cystein residues. A single cysteine residue is added to permit accurate quantification of the protein enriched from producing bacteria. A His tag is also present for protein enrichment. 
the QconCAT strategy is that once the QconCAT gene is cloned, the corresponding protein can be produced, labeled, and quantified on demand. It is worth to take into account that due to their lack of folding, QconCAT concatamers behave differently under proteolysis (Rivers et al., 2007). A way to avoid this bias and replicate the proteolysis is surrounding each proteotypic peptide in the concatamer with its native flanking sequences (Kito et al., 2007). A comparative study between chemical synthesis and recombinant genetic approach concludes that the equimolarity of the QconCAT digest was most significantly affected by digestion conditions, whereas resolubilization, degradation, and peptide modifications were the most critical factors affecting equimolarity of synthetic peptides (Mirzaei et al., 2008). Furthermore, QconCAT methodology was used to create a standard for optimization and standardization of instrument performance named QCAL (Eyers et al., 2008). In summary, QconCAT has the main advantage of multiplexing protein quantification but the QconCAT concatamer is added late to the quantitative process, sharing the same drawback that AQUA peptides and not being compatible with previous protein-based sample fractionation.

\section{Protein Standard Absolute Quantification (PSAQ)}

The most recently described isotope dilution approach uses in vitro-synthesized isotope labeled full-length proteins as standards for absolute quantification, this is being commercialized by Promise Advanced Proteomics (Grenoble, Grenoble, France) (Brun et al., 2007). PSAQ appears as an interesting technique to overcome the bias introduces by digestion and sample pre-fractionation steps as AQUA and QconCAT standards are usually introduced at late stages on the analytical process. Such a standard can be added to the sample at the very beginning of the analytical process post-cellular lysis or directly into a biofluid preventing differences on digestion and/or fractionation of the sample. Indeed, PSAQ has been successfully combined with SDS-PAGE (Brun et al., 2009) and immunocapture (Dupuis et al., 2008) and it has been used successfully to measure the amount of a therapeutic monoclonal antibody in serum (Heudi et al., 2008). However, the major drawback of PSAQ approach is the high cost and the expertise required to produce these protein standards.

\section{BIOMARKER DISCOVERY}

At the turn of the century, proteomics has been increasingly applied to the search of biomarkers (Fig. 7). An important advantage of proteomics relies on the possibility to provide non-invasive biomarkers by the analysis of body fluids such as blood or urine. Biomarkers are defined as endogenous or injected molecules whose presence or metabolism correlates with important disease related physiological processes and or disease outcomes. There is an increasing interest in applying proteomics to foster and improved understanding of the molecular basis of different diseases, developing biomarkers for early diagnosis and monitoring the efficacy and response of new therapies through the observation of protein networks (Jain, 2004; Kolch et al., 2005; Rajapakse et al., 2005). Hence, proteomics has been used broadly as an important component of biomedical and clinical research (Feng et al., 2000; Chen
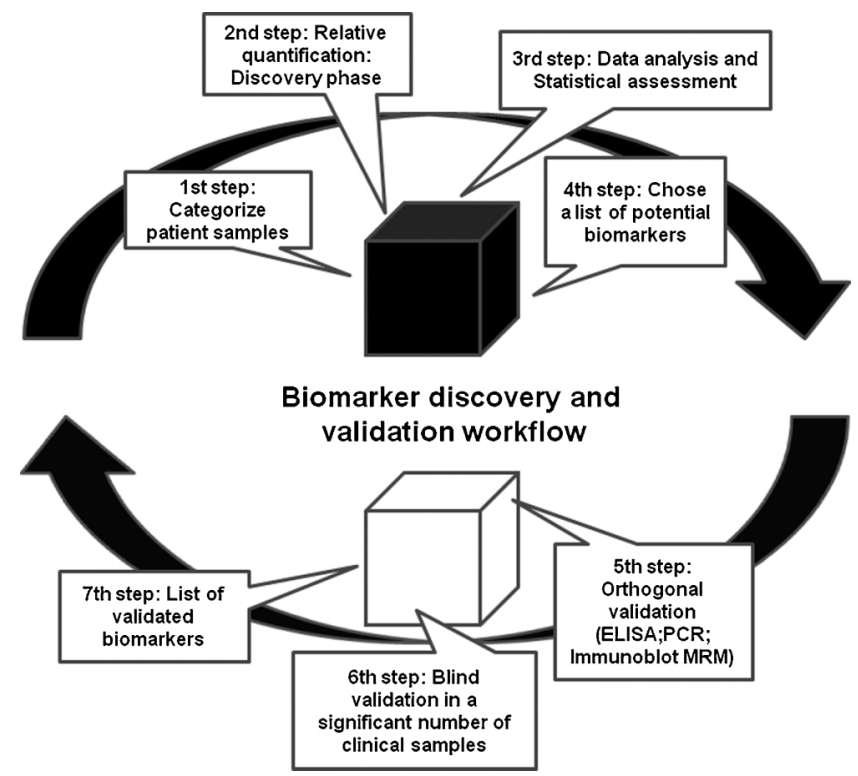

FIGURE 7. Biomarker discovery and validation workflow.

et al., 2005; Drake et al., 2005; González-Buitrago et al., 2007; Matharoo-Ball et al., 2007).

However, the process for mass-spectrometry biomarker discovery requires following a complicated workflow from the collection of well-defined clinical samples to the validation of the markers found in large-scale comparative proteomic studies. Hence, one of the most important challenges in biomarker discovery is the lack of a well-defined cohort of controls which together with the huge biological variability among patients and collected clinical material, as well as the huge dynamic range of proteins in the samples makes it extremely difficult to derive clinically relevant data for prognosis, diagnosis, and response to therapy or toxicity. It is also becoming clear that mapping several rather than individual markers may be necessary for robust diagnostic, prognostic, or toxicological indicator test development (Cho, 2007). Another point to take into consideration is that without independent, large validation studies in clinical trials, unreasonable conclusions and false expectations could be created which is, indeed, detrimental to the mass spectrometry and proteomics community. Hence, after the sample collection and associated clinical data the relative quantification studies can be performed following a good experimental design. A valuable data interpretation followed by appropriate statistical analysis can give us few candidate markers, which could be extensively validated in blinded samples.

Until very recently, mass spectrometry has been used exclusively to foster new biomarkers in large-scale studies, whereas their verification and validation has been carried out by higher throughput affinity methods such as ELISA. Nowadays, targeted MS methods such as SRM have the potential to bridge the gap between biomarker discovery and validation studies before clinical trials due to its sensitivity and reproducibility, as has been discussed previously. In the SRM method the researchers first decide which proteins they want to focus on and then they measure them with very high accuracy and reproducibility. This has the potential to speed-up the 
validation and verification process. But, unfortunately, although this workflow can be amenable to work with tissue samples, most of the know biomarkers in blood occur at very low abundance and would not be revealed by large-scale proteomic techniques. Hence, some researchers use previous studies in the literature such as those generating large transcriptomic datasets to define a set of candidate biomarkers, as these studies can shed light on a specific pathway which could be a candidate source of biomarkers for follow-up experiments (Vogelstein \& Kinzler, 2004; Harris \& McCormick, 2010). Furthermore, if a pathway changes regarding transcriptome data, SRM on targeted proteins can clarify if these mRNA changes are being translate to protein changes. These approaches are of significant value but it is important to remember that mRNA is an intermediate in changes in cell phenotype and the production of new proteins depends on several processes involved in their regulation such as mRNA translation rate, protein degradation rate, post-translational modifications or alternative splicing. Numerous studies suggested a weak concordance between mRNA changes and protein levels (Harris et al., 2004; Maziarz et al., 2005; Khositseth et al., 2011), hence, although transcriptomics gives greater coverage than proteomics due to its greater dynamic range, proteomics can identify splice variants and post-translation modifications (PTMs) plus true protein levels which inevitably plays an important role in protein function and consequently, in pathological stages (Pritsker \& Lemischka, 2006; Unwin et al., 2006). Obviously, many proteomic changes would not therefore be reflected as transcriptome changes and the proteome analysis adds biological information and a deeper knowledge of the biosystem under study. Therefore, despite the caveats described for both methodologies, both approaches can be used as complementary source of information to understand diseases and shotgun protein profiling methods can be used to guide the interpretation of microarray data validating the results of a transcriptomic study.

Another promising approach, which is being currently explored, is the identification of cancer biomarkers of serum for auto-antibodies against tumor proteins (Anderson et al., 2010; Wright et al., 2010). Also, the use of disease models like knock-out mice, can shed light on several diseases at different pathological stages, and provided a well control cohort of study without the challenging of the huge variability that offer human samples (Kelly-Spratt et al., 2008). Alternatively, several studies have found that secreted proteins of tumor cells in cell culture can be an excellent source of biomarkers (Volmer et al., 2005; Kulasingam \& Diamandis, 2007).

Despite all the challenging behind a biomarker study, mass spectrometry remains at the core of the expanding effort to deal with disease-driven studies. Therefore, recently, in an attempt to avoid the invasive procedure required for diagnosis of Trisomy 21 that carries a risk of miscarriage, mass spectrometry and proteomics was applied for the discovery of new putative biomarkers for Trisomy 21 through quantitative SRM assays in maternal serum (Lopez et al., 2010). Also, proteomic technologies together with bioinformatics have been used to identify molecular signatures of individual tumors (Gulmann et al., 2006). A set of biomarkers have been reported for myriad of diseases: cardiovascular diseases (Anderson, 2005), prostate cancer (Fan et al., 2010), rheumatoid arthritis (Kuhn, 2004), ovarian cancer (Visintin et al., 2008), hepatocellular carcinoma (Chaerkady et al., 2008), lymphoma (Kamper et al., 2011), sclerosis (Carlsson et al., 2011), colorectal cancer (Murakoshi et al., 2011), lung cancer (Ostroff et al., 2010), Alzheimer (Craig-Schapiro et al., 2011), ischemia (Stapels et al., 2010).

Despite all these efforts, conversion of a putative biomarker to general use in the clinic changing diagnostic practice or disease management is a relatively rare event. The above review has significance in enabling identification of the pathway best suited to obtaining the desired outcome, robust markers of medical and veterinary value.

\section{PROGRESS TO DATE AND FUTURE CHALLENGES}

Over the last few years, mass spectrometry has improved greatly in sensitivity and accuracy and thus proteomics evolved from having difficulties in identifying just a few proteins in a mixture to correctly assign more than 2,500 proteins within a single LC-MS/MS run. The substantial progress made in instrumentation coupled with improvements in database searching and data curation has led to a rapid movement of the field from qualitative to quantitative proteomics. Some of the key features requested to a mass spectrometer include resolution, mass measurement accuracy (MMA), attomole sensitivity, and fast spectral acquisition rates.

Hence, lower resolution instruments have been replaced by hybrid Fourier transform MS technology (FTMS), including linear trap quadrupole (Syka, 2004) and LTQ-Orbitrap (Olsen et al., 2005). Commercially, the Orbitrap analyzer was first introduced in 2005 in a hybrid instrument and it has become a major instrument in shotgun proteomics experiments (Syka, 2004). The combination of a low resolution linear ion trap with a high resolution analyzer makes this instrument extremely attractive for performing accurate shotgun quantitative proteomic experiments, offering versatile fragmentation modes depending on the analytical problem (McAlister et al., 2008; McAlister et al., 2011). Additionally, the combination of a quadrupole mass filter with the Orbitrap analyzer has been established and shows a substantial increase in speed for proteomic analyses (Michalski et al., 2011). Also, the recently introduced triple ToF platform (TripleTOF ${ }^{\mathrm{TM}}$ 5600, AB SCIEX Instruments) has an impressive increase in sensitivity and dynamic range as compared to its predecessors (A. Whetton, unpublished observations). This instrument claims to achieve 4 orders of linear dynamic range in accurate quantification and as a result is considered the first accurate mass, high resolution system of his kind operating with the speed and sensitivity of a TOF MS and quantification capabilities similar to a triple quadrupole MS (Andrews et al., 2011).

But the current offer in new mass spectrometry instruments still does not exceed the sensitivity on quantification required for some of the validation biomarker experiments required by the biomedicine, life science and proteomic research communities and neither reaches the dynamic range power required to perform complex studies of biomarkers in body fluids such as plasma or urine. Hence, a study using mass spectrometry and isotopic labeling claimed to monitor changes in the abundance of yeast proteins from 50,000 molecules per cell to 5,000 molecules per cell. For the most abundant proteins the coverage was really high (up to 60\%) but for 
the $75 \%$ of the proteome that is present at fewer than 5,000 molecules per cell, only $8 \%$ of the proteins were detected (Washburn et al., 2003). Nowadays, the most sensitive mass spectrometry method is SRM on a triple quadrupole (QQQ) platform which allows quantification of protein in plasma with a dynamic range of 4-5 orders of magnitude and a sensitivity of $1 \mu \mathrm{g} / \mathrm{mL}$ (Surinova et al., 2010). Unfortunately, SRM is not powerful enough by itself as the aim of plasma proteome analysis is to study proteins with a concentration under $100 \mathrm{ng} /$ $\mathrm{mL}$. However, important improvements on these techniques are being achieved. Thus, Picotti et al. measure the power of this analytical approach selecting a set of 100 target proteins based on a previous list of absolute proteins abundances of Saccharomyces cerevisiae generated by orthogonal methods. These target proteins were evenly distributed across all levels of cellular abundance from 1.3E6 to 41 copies per cell. Hence, covering a dynamic range of 4.5 orders of magnitude it was demonstrated that SRM-based proteomics has the power to reliably detect proteins down to a concentration of 50 copies per cell in a $S$. cerevisiae protease digest without a previous pre-fractionation of the sample (Picotti et al., 2009).

Another strategy adopted to overcome this dynamic range issue is immunodepletion or enrichment techniques. The seven most abundant proteins in serum (albumin, immunoglobulins both large and small chains, transferrin, $\alpha$-macroglobulin, antitrypsin, and haptoglobulin) already amount to $90 \%$ of the total serum proteins and it is known that some additional 30 proteins are present in the greater than $\mu \mathrm{g} / \mathrm{mL}$ range (Zolg \& Langen, 2004). Furthermore, one study estimated that 22 proteins comprise approximately $99 \%$ of plasma protein content. The remaining $1 \%$ of the total plasma proteome has a dynamic range of $10^{7}$-fold and all putative biomarkers are expected to be in this sub-proteome (Tirumalai et al., 2003). Consequently, high abundance protein removal is just the first step to reduce proteome complexity in plasma and further fractionation steps must be required to achieve the desirable substrate of the plasma proteome to identify real biomarkers (Zolg, 2006). To reduce the sample complexity isolation of a subproteome based on protein modification like glycosylation has been also explored (Zhang et al., 2003). Furthermore, SRM analysis of glycoproteins in plasma has reached levels of detection of $5 \mathrm{ng} / \mathrm{mL}$. In 2005 a novel affinity approach was introduced (ProteoMiner (Bio-Rad, Berkeley, CA) or Equalizer beads), which reduces the dynamic range of the proteome with a large and diverse library of hexapeptides bound to a chromatographic support. Despite some reported issues with this emerging technology (Keidel et al., 2010), others have found similar performance after comparing both strategies, obtaining partially overlapping results (Millioni et al., 2011). An alternative to the depletion strategies is to increase the gradients length with high resolution coupled to an instrument with fast sequencing speed (Thakur et al., 2011).

Overall, the final stage of any quantitative proteomic analysis is to draw a biological conclusion from a numeric result. Therefore, combined efforts of bioinformaticians, biologists, and biomedical researchers have taken place to develop strategies and applications to help researchers to answer biological questions through taking this data as a starting point whilst not becoming overwhelmed by the amount of information. There are numerous software packages to order proteomic datasets. These are based on gene ontology, pathway analysis and interaction networks as well as dataset public repositories (Dennis et al., 2003; Mi et al., 2005; Kanehisa et al., 2008; Vizcaíno et al., 2009). Hence, with the ability of mass spectrometers to analyze complex samples, software development plays a crucial role and must be a dynamic process, which should be expanded together with technical advances in the instrumentation.

\section{CONCLUSIONS}

The methods described above are crucial in the discovery and validation phases of biomarkers and information for systematic understanding of biological systems. Overall, the complex nature of proteomics experiments requires more effective translation into understanding and measuring the differences between the healthy and diseased organism. It is worth recapping some of the issues that make this an off traveled road with many pitfalls. MS now has a capacity to identify and quantify proteins in complex mixtures. However, dynamic range issues mean we often measure the same higher abundance proteins and lower abundance proteins remain un-analyzed. Simple profiling of biofluids which contain complex mixtures is not very successful approach, hence it is important to fractionate the sample prior to analysis otherwise the most abundant proteins obscure signals from less abundant ones. The corollary of this is that errors are generated in fractionation procedures. Therefore, candidate biomarkers will need to be identified with the best available methods balancing accuracy, precision, multiplexing, and opportunities for orthogonal validation (Aebersold et al., 2005). The above methods offer opportunities for relatively stable platforms and the field has advanced markedly in the last 10 years. Nevertheless, the belief that measuring low abundance proteins with off the shelf SRM transitions in multiple samples with high accuracy is easy and achievable in many laboratories is presently distinctly challengeable. The above techniques do offer huge opportunities and we have pointed out these and pitfalls also.

Overall, continued improvement of technologies and methods to determine the abundance of proteins holds a great promise for the future study of human disease towards personalized medicine and a systematic understanding of physiology and pathology at the molecular level.

\section{ABBREVIATIONS}

2D-DIGE two-dimensional differential gel electrophoresis 2D-PAGE two-dimensional polyacrylamide gel electrophoresis AMRT accurate mass retention time

APEX absolute protein expression

CAD collisionally activated dissociation

COFRADIC combined fractional-diagonal chromatography

DIA data independent acquisition method

ELISA enzyme-linked immunosorbant assay

emPAI exponentially modified protein abundance index

ESI electrospray ionization

ETD electron transfer dissociation

FASP filter-aided sample preparation method

FTMS Fourier transform MS

HCD higher energy C-trap dissociation

HPLC high performance liquid chromatography

ICAT isotope-coded affinity tag 


$\begin{array}{ll}\text { iSRM } & \text { intelligent selected reaction monitoring } \\ \text { iTRAQ } & \text { isobaric tag for relative and absolute quantitation } \\ \text { LC-MS/MS } & \text { liquid chromatography tandem mass spectrometry } \\ \text { MMA } & \text { mass measurement accuracy } \\ \text { MIDAS } & \text { MRM initiated detection and sequencing } \\ \text { MRM } & \text { multiple reaction monitoring } \\ \text { MudPIT } & \text { multidimensional protein identification technology } \\ \text { NSAF } & \text { normalized spectral abundance factor } \\ \text { PA } & \text { protein abundance index } \\ \text { PLGS } & \text { protein lynx global server } \\ \text { PMSS } & \text { peptide match score summation } \\ \text { PQD } & \text { pulsed Q dissociation } \\ \text { PSAQ } & \text { protein standard absolute quantitation } \\ \text { PTMs } & \text { post-translation modifications } \\ \text { QconCAT } & \text { quantification concatamer } \\ \text { QQQ } & \text { triple quadrupole } \\ \text { QqQ-LIT } & \text { triple-quadrupole-linear ion trap hybrid } \\ \text { instrument } \\ \text { RP } & \text { reversed phase (chromatography) } \\ \text { RT } & \text { retention times } \\ \text { SC } & \text { spectral count } \\ \text { SIC } & \text { single ion chromatogram } \\ \text { SCX } & \text { strong cation exchange } \\ \text { SDS } & \text { sodium dodecyl sulfate } \\ \text { SID } & \text { stable isotope dilution } \\ \text { SIL } & \text { stable isotopic labeling } \\ \text { SILAC } & \text { stable isotope labeling by amino acids in cell } \\ \text { culture } & \text { normalized spectral index } \\ \text { SIN } & \text { stable isotope standards and capture by anti- } \\ \text { SISCAPA } & \text { peptide antibodies } \\ \text { selective reaction monitoring } \\ \text { TPMP } & \text { targeted identification for quantitative analysis } \\ \text { UPLC } & \text { by multiple reaction monitoring } \\ \text { tandem mass tags } \\ \text { time of flight } \\ \text { trans-proteomic pipeline } \\ \text { ultra performance liquid chromatography } \\ \end{array}$

\section{ACKNOWLEDGMENTS}

Work in the authors' laboratories is supported by Leukaemia Lymphoma Research, Cancer Research UK, CIBERehd and ProteoRed.

\section{REFERENCES}

Aebersold R. 2003. Constellations in a cellular universe. Nature 422:115116.

Aebersold R, Anderson L, Caprioli R, Druker B, Hartwell L, Smith R. 2005. Perspective: A program to improve protein biomarker discovery for cancer. J Proteome Res 4:1104-1109.

Alban A, David SO, Bjorkesten L, Andersson C, Sloge E, Lewis S, Currie I. 2003. A novel experimental design for comparative two-dimensional gel analysis: Two-dimensional difference gel electrophoresis incorporating a pooled internal standard. Proteomics 3:36-44.

Allet N. 2004. In vitro and in silico processes to identify differentially expressed proteins. Proteomics 4:2333-2351.

Alpert AJ. 1990. Hydrophilic-interaction chromatography for the separation of peptides, nucleic acids and other polar compounds. J Chromatogr A 499:177-196.
America AHP, Cordewener JHG. 2008. Comparative LC-MS: A landscape of peaks and valleys. Proteomics 8:731-749.

Amon LM, Law W, Fitzgibbon MP, Gross JA, O'Briant K, Peterson A Drescher C, Martin DB, McIntosh M. 2010. Integrative proteomic analysis of serum and peritoneal fluids helps identify proteins that are up-regulated in serum of women with ovarian cancer. PLoS ONE 5:e11137.

Anderson L. 2005. Candidate-based proteomics in the search for biomarkers of cardiovascular disease. J Physiology 563:23-60.

Anderson NL, Anderson NG. 2002. The human plasma proteome. Mol Cell Proteomics 1:845-867.

Anderson L, Hunter CL. 2006. Quantitative mass spectrometric multiple reaction monitoring assays for major plasma proteins. Mol Cell Proteomics 5:573-588.

Anderson NL, Anderson NG, Haines LR, Hardie DB, Olafson RW, Pearson TW. 2004. Mass spectrometric quantitation of peptides and proteins using stable isotope standards and capture by anti-peptide antibodies (SISCAPA). J Proteome Res 3:235-244.

Anderson KS, Wong J, Vitonis A, Crum CP, Sluss PM, LaBaer J, Cramer D. 2010. p53 autoantibodies as potential detection and prognostic biomarkers in serous ovarian cancer. Cancer Epidemiol Biomarkers Prev 19:859-868.

Andrews GL, Simons BL, Young JB, Hawkridge AM, Muddiman DC 2011. Performance characteristics of a new hybrid quadrupole timeof-flight tandem mass spectrometer (TripleTOF 5600). Anal Chem 83:5442-5446.

Bantscheff M, Schirle M, Sweetman G, Rick J, Kuster B. 2007. Quantitative mass spectrometry in proteomics: A critical review. Anal Bioanalytical Chemistry 389:1017-1031.

Bantscheff M, Boesche M, Eberhard D, Matthieson T, Sweetman G, Kuster B. 2008. Robust and sensitive iTRAQ quantification on an LTQ orbitrap mass spectrometer. Mol Cell Proteomics 7:1702-1713.

Barr J, Maggio V, Patterson D, Jr., Cooper G, Henderson L, Turner W, Smith S, Hannon W, Needham L, Sampson E. 1996. Isotope dilution-mass spectrometric quantification of specific proteins: Model application with apolipoprotein A-I. Clin Chem 42:1676-1682.

Bateman RH, Carruthers R, Hoyes JB, Jones C, Langridge JI, Millar A, Vissers JPC. 2002. A novel precursor ion discovery method on a hybrid quadrupole orthogonal acceleration time-of-flight (Q-TOF) mass spectrometer for studying protein phosphorylation. J Am Soc Mass Spectrom 13:792-803.

Bellew M, Coram M, Fitzgibbon M, Igra M, Randolph T, Wang P, May D, Eng J, Fang R, Lin C, Chen J, Goodlett D, Whiteaker J, Paulovich A, McIntosh M. 2006. A suite of algorithms for the comprehensive analysis of complex protein mixtures using high-resolution LCMS. Bioinformatics 22:1902-1909.

Belov ME, Rakov VS, Nikolaev EN, Goshe MB, Anderson GA, Smith RD. 2003. Initial implementation of external accumulation liquid chromatography/electrospray ionization Fourier transform ion cyclotron resonance with automated gain control. Rapid Commun Mass Spectrom 17:627-636.

Besson D, Pavageau A-H, Valo I, Bourreau A, Bélanger A, Eymerit-Morin C, Moulière A, Chassevent A, Boisdron-Celle M, Morel A, Solassol J, Campone M, Gamelin E, Barré B, Coqueret O, Guette C. 2011. A quantitative proteomic approach of the different stages of colorectal cancer establishes OLFM4 as a new nonmetastatic tumor marker. Mol Cell Proteomics 10(12):M111.009712.

Bewley MA, Pham TK, Marriott HM, Noirel J, Chu H-P, Ow SY, Ryazanov AG, Read RC, Whyte MKB, Chain B, Wright PC, Dockrell DH. 2011. Proteomic evaluation and validation of cathepsin D regulated proteins in macrophages exposed to Streptococcus pneumoniae. Mol Cell Proteomics 10(6):M111.008193.

Beynon RJ, Pratt JM. 2005. Metabolic labeling of proteins for proteomics. Mol Cell Proteomics 4:857-872.

Beynon RJ, Doherty MK, Pratt JM, Gaskell SJ. 2005. Multiplexed absolute quantification in proteomics using artificial QCAT proteins of concatenated signature peptides. Nat Methods 2:587-589. 
Bicho CC, de Lima Alves F, Chen ZA, Rappsilber J, Sawin KE. 2010. A genetic engineering solution to the "arginine conversion problem" in stable isotope labeling by amino acids in cell culture (SILAC). Mol Cell Proteomics 9:1567-1577.

Blagoev B, Ong SE, Kratchmarova I, Mann M. 2004. Temporal analysis of phosphotyrosine-dependent signaling networks by quantitative proteomics. Nat Biotechnol 22:1139-1145.

Bondar OP, Barnidge DR, Klee EW, Davis BJ, Klee GG. 2007. LC-MS/ MS quantification of $\mathrm{Zn}$-\{alpha\}2 glycoprotein: A potential serum biomarker for prostate cancer. Clin Chem 53:673-678.

Bondarenko PV, Chelius D, Shaler TA. 2002. Identification and relative quantitation of protein mixtures by enzymatic digestion followed by capillary reversed-phase liquid chromatography-Tandem mass spectrometry. Anal Chem 74:4741-4749.

Bostanci N, Heywood W, Mills K, Parkar M, Nibali L, Donos N. 2010. Application of label-free absolute quantitative proteomics in human gingival crevicular fluid by LC/MSE (gingival exudatome). J Proteome Res 9:2191-2199.

Boumahrou N, Bevilacqua C, Beauvallet C, Miranda G, Andrei S, Rebours E, Panthier J-J, Bellier S, Martin P. 2011. Evolution of major milk proteins in Mus musculus and Mus spretus mouse species: A genoproteomic analysis. BMC Genomics 12:80.

Braisted J, Kuntumalla S, Vogel C, Marcotte E, Rodrigues A, Wang R, Huang S-T, Ferlanti E, Saeed A, Fleischmann R, Peterson S, Pieper R. 2008. The APEX Quantitative Proteomics Tool: Generating protein quantitation estimates from LC-MS/MS proteomics results. BMC Bioinformatics 9:529.

Brun V, Dupuis A, Adrait A, Marcellin M, Thomas D, Court M, Vandenesch F, Garin J. 2007. Isotope-labeled protein standards. Mol Cell Proteomics 6:2139-2149.

Brun V, Masselon C, Garin J, Dupuis A. 2009. Isotope dilution strategies for absolute quantitative proteomics. J Proteomics 72:740-749.

Burkhart JM, Vaudel M, Zahedi RP, Martens L, Sickmann A. 2011. iTRAQ protein quantification: A quality-controlled workflow. Proteomics 11:1125-1134

Carlsson A, Wuttge DM, Ingvarsson J, Bengtsson AA, Sturfelt G, Borrebaeck CAK, Wingren C. 2011. Serum protein profiling of systemic lupus erythematosus and systemic sclerosis using recombinant antibody microarrays. Mol Cell Proteomics 10(5):M110.005033.

Carreira RJ, Rial-Otero R, López-Ferrer D, Lodeiro C, Capelo JL. 2008. Ultrasonic energy as a new tool for fast isotopic $18 \mathrm{O}$ labeling of proteins for mass spectrometry-based techniques: Preliminary results. Talanta 76:400-406.

Chaerkady R, Harsha HC, Nalli A, Gucek M, Vivekanandan P, Akhtar J, Cole RN, Simmers J, Schulick RD, Singh S, Torbenson M, Pandey A, Thuluvath PJ. 2008. A quantitative proteomic approach for identification of potential biomarkers in hepatocellular carcinoma. J Proteome Res 7:4289-4298.

Chalkley RJ, Baker PR, Huang L, Hansen KC, Allen NP, Rexach M, Burlingame AL. 2005. Comprehensive analysis of a multidimensional liquid chromatography mass spectrometry dataset acquired on a quadrupole selecting, quadrupole collision cell, time-of-flight mass spectrometer. Mol Cell Proteomics 4:1194-1204.

Chambery A, Colucci-D'Amato L, Vissers JPC, Scarpella S, Langridge JI, Parente A. 2008. Proteomic profiling of proliferating and differentiated neural mes-c-myc A1 cell line from mouse embryonic mesencephalon by LC-MS. J Proteome Res 8:227-238.

Chelius D, Bondarenko PV. 2002. Quantitative profiling of proteins in complex mixtures using liquid chromatography and mass spectrometry. J Proteome Res 1:317-323.

Chen R, Pan S, Brentnall TA, Aebersold R. 2005. Proteomic profiling of pancreatic cancer for biomarker discovery. Mol Cell Proteomics 4:523-533.

Chen EI, Cociorva D, Norris JL, Yates JR. 2007. Optimization of mass spectrometry-compatible surfactants for shotgun proteomics. J Proteome Res 6:2529-2538.
Cheng D, Hoogenraad CC, Rush J, Ramm E, Schlager MA, Duong DM, Xu P, Wijayawardana SR, Hanfelt J, Nakagawa T, Sheng M, Peng J. 2006. Relative and absolute quantification of postsynaptic density proteome isolated from rat forebrain and cerebellum. Mol Cell Proteomics 5:1158-1170.

Chick JM, Haynes PA, Bjellqvist B, Baker MS. 2008. A Combination of immobilised ph gradients improves membrane proteomics. J Proteome Res 7:4974-4981.

Cho W. 2007. Contribution of oncoproteomics to cancer biomarker discovery. Mol Cancer 6:25.

Choe L, D'Ascenzo M, Relkin NR, Pappin D, Ross P, Williamson B, Guertin S, Pribil P, Lee KH. 2007. 8-Plex quantitation of changes in cerebrospinal fluid protein expression in subjects undergoing intravenous immunoglobulin treatment for Alzheimer's disease. Proteomics 7:3651-3660.

Choi YS, Choe LH, Lee KH. 2010. Recent cerebrospinal fluid biomarker studies of Alzheimer's disease. Expert Rev Proteomics 7:919-929.

Cima I, Schiess R, Wild P, Kaelin M, Schüffler P, Lange V, Picotti P, Ossola R, Templeton A, Schubert O, Fuchs T, Leippold T, Wyler S, Zehetner J, Jochum W, Buhmann J, Cerny T, Moch H, Gillessen S, Aebersold R, Krek W. 2011. Cancer genetics-guided discovery of serum biomarker signatures for diagnosis and prognosis of prostate cancer. Proc Natl Acad Sci 108:3342-3347.

Colinge J, Chiappe D, Lagache S, Moniatte M, Bougueleret L. 2004. Differential proteomics via probabilistic peptide identification scores. Anal Chem 77:596-606.

Conrad D, Goyette J, Thomas P. 2008. Proteomics as a method for early detection of cancer: A review of proteomics, exhaled breath condensate, and lung cancer screening. J Gen Intern Med 23:78-84.

Corthals GL, Wasinger VC, Hochstrasser DF, Sanchez J-C. 2000. The dynamic range of protein expression: A challenge for proteomic research. Electrophoresis 21:1104-1115.

Craig-Schapiro R, Kuhn M, Xiong C, Pickering EH, Liu J, Misko TP, Perrin RJ, Bales KR, Soares H, Fagan AM, Holtzman DM. 2011. Multiplexed immunoassay panel identifies novel CSF biomarkers for Alzheimer's disease diagnosis and prognosis. PLoS ONE 6: e18850.

Dahlhaus M, Wan Li K, van der Schors RC, Saiepour MH, van Nierop P, Heimel JA, Hermans JM, Loos M, Smit AB, Levelt CN. 2011. The Synaptic proteome during development and plasticity of the mouse visual cortex. Mol Cell Proteomics 10(5):M110.005413.

D'Ascenzo M, Choe L, Lee KH. 2008. iTRAQPak: An R based analysis and visualization package for 8-plex isobaric protein expression data. Briefings Funct Genomics Proteomics 7:127-135.

Dave KA, Whelan F, Bindloss C, Furness SGB, Chapman-Smith A, Whitelaw ML, Gorman JJ. 2009. Sulfonation and phosphorylation of regions of the dioxin receptor susceptible to methionine modifications. Mol Cell Proteomics 8:706-719.

Dayon L, Hainard A, Licker V, Turck N, Kuhn K, Hochstrasser DF, Burkhard PR, Sanchez J-C. 2008. Relative quantification of proteins in human cerebrospinal fluids by MS/MS using 6-plex isobaric tags. Anal Chem 80:2921-2931.

de Godoy L, Olsen J, de Souza G, Li G, Mortensen P, Mann M. 2006. Status of complete proteome analysis by mass spectrometry: SILAC labeled yeast as a model system. Genome Biol 7:R50.

de Souza GA, Fortuin S, Aguilar D, Pando RH, McEvoy CRE, van Helden PD, Koehler CJ, Thiede B, Warren RM, Wiker HG. 2010. Using a label-free proteomics method to identify differentially abundant proteins in closely related hypo- and hypervirulent clinical mycobacterium tuberculosis Beijing isolates. Mol Cell Proteomics 9:2414-2423.

Dennis G, Sherman B, Hosack D, Yang J, Gao W, Lane HC, Lempicki R. 2003. DAVID: Database for annotation, visualization, and integrated discovery. Genome Biol 4:P3.

Dephoure N, Zhou C, Villén J, Beausoleil SA, Bakalarski CE, Elledge SJ, Gygi SP. 2008. A quantitative atlas of mitotic phosphorylation. Proc Natl Acad Sci 105:10762-10767. 
Desiderio DM, Kai M. 1983. Preparation of stable isotope-incorporated peptide internal standards for field desorption mass spectrometry quantification of peptides in biologic tissue. Biomed Mass Spectrom 10:471.

Deutsch EW, Lam H, Aebersold R. 2008. PeptideAtlas: A resource for target selection for emerging targeted proteomics workflows. EMBO Rep 9:429-434

Doherty MK, Whitehead C, McCormack H, Gaskell SJ, Beynon RJ. 2005. Proteome dynamics in complex organisms: Using stable isotopes to monitor individual protein turnover rates. Proteomics 5:522-533.

Domon B, Aebersold R. 2006. Mass spectrometry and protein analysis. Science 312:212-217.

Drake RR, Cazares LH, Semmes OJ, Wadsworth JT. 2005. Serum, salivary and tissue proteomics for discovery of biomarkers for head and neck cancers. Expert Rev Mol Diagn 5:93-100.

Duncan MW, Roder H, Hunsucker SW. 2008. Quantitative matrix-assisted laser desorption/ionization mass spectrometry. Briefings Funct Genomics Proteomics 7:355-370.

Duncan MW, Yergey AL, Patterson SD. 2009. Quantifying proteins by mass spectrometry: The selectivity of SRM is only part of the problem. Proteomics 9:1124-1127.

Dupuis A, Hennekinne J-A, Garin J, Brun V. 2008. Protein Standard Absolute Quantification (PSAQ) for improved investigation of staphylococcal food poisoning outbreaks. Proteomics 8:4633-4636.

Eyers C, Simpson D, Wong S, Beynon R, Gaskell S. 2008. QCAL-A novel standard for assessing instrument conditions for proteome analysis. J Am Soc Mass Spectrom 19:1275-1280.

Faca VM, Song KS, Wang H, Zhang Q, Krasnoselsky AL, Newcomb LF, Plentz RR, Gurumurthy S, Redston MS, Pitteri SJ, Pereira-Faca SR, Ireton RC, Katayama $\mathrm{H}$, Glukhova V, Phanstiel D, Brenner DE, Anderson MA, Misek D, Scholler N, Urban ND, Barnett MJ, Edelstein C, Goodman GE, Thornquist MD, McIntosh MW, DePinho RA, Bardeesy N, Hanash SM. 2008. A mouse to human search for plasma proteome changes associated with pancreatic tumor development. PLoS Med 5:e123.

Fan Y, Murphy TB, Byrne JC, Brennan L, Fitzpatrick JM, Watson RWG. 2010. Applying random forests to identify biomarker panels in serum 2D-DIGE data for the detection and staging of prostate cancer. J Proteome Res 10:1361-1373.

Feng JT, Shang S, Beretta L. 2000. Proteomics for the early detection and treatment of hepatocellular carcinoma. Oncogene 25:3810-3817.

Fernández-de-Cossio J, Gonzalez LJ, Satomi Y, Betancourt L, Ramos Y, Huerta V, Besada V, Padron G, Minamino N, Takao T. 2004. Automated interpretation of mass spectra of complex mixtures by matching of isotope peak distributions. Rapid Commun Mass Spectrom 18:2465-2472.

Fernández-Puente P, Mateos J, Fernández-Costa C, Oreiro N, FernándezLópez C, Ruiz-Romero C, Blanco FJ. 2011. Identification of a panel of novel serum osteoarthritis biomarkers. J Proteome Res 10:50955101.

Florens L, Carozza MJ, Swanson SK, Fournier M, Coleman MK, Workman JL, Washburn MP. 2006. Analyzing chromatin remodeling complexes using shotgun proteomics and normalized spectral abundance factors. Methods 40:303-311.

Foster LJ, de Hoog CL, Zhang Y, Zhang Y, Xie X, Mootha VK, Mann M. 2006. A mammalian organelle map by protein correlation profiling. Cell 125:187-199.

Gao H, Materne OL, Howe DL, Brummel CL. 2007. Method for rapid metabolite profiling of drug candidates in fresh hepatocytes using liquid chromatography coupled with a hybrid quadrupole linear ion trap. Rapid Commun Mass Spectrom 21:3683-3693.

Gauci S, Helbig AO, Slijper M, Krijgsveld J, Heck AJR, Mohammed S. 2009. Lys-N and trypsin cover complementary parts of the phosphoproteome in a refined SCX-based approach. Anal Chem 81:44934501
Ge Y, Rajkumar L, Guzman RC, Nandi S, Patton WF, Agnew BJ. 2004. Multiplexed fluorescence detection of phosphorylation, glycosylation, and total protein in the proteomic analysis of breast cancer refractoriness. Proteomics 4:3464-3467.

Geiger T, Wisniewski JR, Cox J, Zanivan S, Kruger M, Ishihama Y, Mann M. 2011. Use of stable isotope labeling by amino acids in cell culture as a spike-in standard in quantitative proteomics. Nat Protoc 6:147-157.

Gerber SA, Rush J, Stemman O, Kirschner MW, Gygi SP. 2003. Absolute quantification of proteins and phosphoproteins from cell lysates by tandem MS. Proc Natl Acad Sci USA 100:6940-6945.

Geromanos SJ, Vissers JPC, Silva JC, Dorschel CA, Li GZ, Gorenstein MV, Bateman RH, Langridge JI. 2009. The detection, correlation, and comparison of peptide precursor and product ions from data independent LC-MS with data dependant LC-MS/MS. Proteomics 9:1683-1695.

Gevaert K, Goethals M, Martens L, Van Damme J, Staes A, Thomas GR, Vandekerckhove J. 2003. Exploring proteomes and analyzing protein processing by mass spectrometric identification of sorted $\mathrm{N}$-terminal peptides. Nat Biotech 21:566-569.

Gevaert K, Staes A, Van Damme J, De Groot S, Hugelier K, Demol H, Martens L, Goethals M, Vandekerckhove J. 2005. Global phosphoproteome analysis on human HepG2 hepatocytes using reversedphase diagonal LC. Proteomics 5:3589-3599.

Ghaemmaghami S, Huh W-K, Bower K, Howson RW, Belle A, Dephoure N, O'Shea EK, Weissman JS. 2003. Global analysis of protein expression in yeast. Nature 425:737-741.

Gilar M, Olivova P, Daly AE, Gebler JC. 2005. Two-dimensional separation of peptides using RP-RP-HPLC system with different $\mathrm{pH}$ in first and second separation dimensions. J Sep Sci 28:1694-1703.

Gilchrist A, Au CE, Hiding J, Bell AW, Fernandez-Rodriguez J, Lesimple S, Nagaya H, Roy L, Gosline SJC, Hallett M, Paiement J, Kearney Robert E, Nilsson T, Bergeron JJM. 2006. Quantitative proteomics analysis of the secretory pathway. Cell 127:1265-1281.

González-Buitrago JM, Ferreira L, Lorenzo I. 2007. Urinary proteomics. Clin Chim Acta 375:49-56.

Gramolini AO, Kislinger T, Alikhani-Koopaei R, Fong V, Thompson NJ, Isserlin R, Sharma P, Oudit GY, Trivieri MG, Fagan A, Kannan A, Higgins DG, Huedig H, Hess G, Arab S, Seidman JG, Seidman CE, Frey B, Perry M, Backx PH, Liu PP, MacLennan DH, Emili A. 2008. Comparative proteomics profiling of a phospholamban mutant mouse model of dilated cardiomyopathy reveals progressive intracellular stress responses. Mol Cell Proteomics 7:519-533.

Griffin TJ, Xie H, Bandhakavi S, Popko J, Mohan A, Carlis JV, Higgins L. 2007. iTRAQ reagent-based quantitative proteomic analysis on a linear ion trap mass spectrometer. J Proteome Res 6:4200-4209.

Griffin NM, Yu J, Long F, Oh P, Shore S, Li Y, Koziol JA, Schnitzer JE. 2010. Label-free, normalized quantification of complex mass spectrometry data for proteomic analysis. Nat Biotech 28:83-89.

Griffiths JR, Unwin RD, Evans CA, Leech SH, Corfe BM, Whetton AD. 2007. The application of a hypothesis-driven strategy to the sensitive detection and location of acetylated lysine residues. J Am Soc Mass Spectrom 18:1423-1428.

Grossmann J, Roschitzki B, Panse C, Fortes C, Barkow-Oesterreicher S, Rutishauser D, Schlapbach R. 2010. Implementation and evaluation of relative and absolute quantification in shotgun proteomics with label-free methods. J Proteomics 73:1740-1746.

Gruhler A. 2005. Quantitative phosphoproteomics applied to the yeast pheromone signaling pathway. Mol Cell Proteomics 4:310-327.

Gulmann C, Sheehan KM, Kay EW, Liotta LA, Petricoin EF. 2006. Array-based proteomics: Mapping of protein circuitries for diagnostics, prognostics, and therapy guidance in cancer. J Pathol 208:595-606.

Guo T, Zhu Y, Gan CS, Lee SS, Zhu J, Wang H, Li X, Christensen J, Huang S, Kon OL, Sze SK. 2010. Quantitative proteomics discloses MET expression in mitochondria as a direct target of MET kinase inhibitor in cancer cells. Mol Cell Proteomics 9:2629-2641. 
Hajkova D, Rao KCS, Miyagi M. 2006. pH dependency of the carboxyl oxygen exchange reaction catalyzed by lysyl endopeptidase and trypsin. J Proteome Res 5:1667-1673.

Halligan B, Slyper R, Twigger S, Hicks W, Olivier M, Greene A. 2005. ZoomQuant: An application for the quantitation of stable isotope labeled peptides. J Am Soc Mass Spectrom 16:302-306.

Han MH, Hwang S-I, Roy DB, Lundgren DH, Price JV, Ousman SS, Fernald GH, Gerlitz B, Robinson WH, Baranzini SE, Grinnell BW, Raine CS, Sobel RA, Han DK, Steinman L. 2008. Proteomic analysis of active multiple sclerosis lesions reveals therapeutic targets. Nature 451:1076-1081.

Harris TJR, McCormick F. 2010. The molecular pathology of cancer. Nat Rev Clin Oncol 7:251-265.

Harris MN, Ozpolat B, Abdi F, Gu S, Legler A, Mawuenyega KG, TiradoGomez M, Lopez-Berestein G, Chen X. 2004. Comparative proteomic analysis of all-trans-retinoic acid treatment reveals systematic posttranscriptional control mechanisms in acute promyelocytic leukemia. Blood 104:1314-1323.

Hart C, Schulenberg B, Steinberg TH, Leung W-Y, Patton WF. 2003. Detection of glycoproteins in polyacrylamide gels and on electroblots using Pro-Q Emerald 488 dye, a fluorescent periodate Schiffbase stain. Electrophoresis 24:588-598.

Havlis J, Shevchenko A. 2004. Absolute quantification of proteins in solutions and in polyacrylamide gels by mass spectrometry. Anal Chem 76:3029-3036.

Hayter JR, Doherty MK, Whitehead C, McCormack H, Gaskell SJ, Beynon RJ. 2005. The subunit structure and dynamics of the $20 \mathrm{~S}$ proteasome in chicken skeletal muscle. Mol Cell Proteomics 4: 1370-1381.

Heinecke NL, Pratt BS, Vaisar T, Becker L. 2010. PepC: Proteomics software for identifying differentially expressed proteins based on spectral counting. Bioinformatics 26:1574-1575.

Helbig AO, Gauci S, Raijmakers R, van Breukelen B, Slijper M, Mohammed S, Heck AJR. 2010. Profiling of N-acetylated protein termini provides in-depth insights into the $\mathrm{N}$-terminal nature of the proteome. Mol Cell Proteomics 9:928-939.

Hemming ML, Elias JE, Gygi SP, Selkoe DJ. 2009. Identification of $\beta$ secretase (BACE1) substrates using quantitative proteomics. PLoS ONE 4:e8477.

Heudi O, Barteau S, Zimmer D, Schmidt J, Bill K, Lehmann N, Bauer C, Kretz O. 2008. Towards absolute quantification of therapeutic monoclonal antibody in serum by LC-MS/MS using isotope-labeled antibody standard and protein cleavage isotope dilution mass spectrometry. Anal Chem 80:4200-4207.

Hoofnagle AN, Becker JO, Wener MH, Heinecke JW. 2008. Quantification of thyroglobulin, a low-abundance serum protein, by immunoaffinity peptide enrichment and tandem mass spectrometry. Clin Chem 54: 1796-1804.

Hoopmann MR, Finney GL, MacCoss MJ. 2007. High-speed data reduction, feature detection, and MS/MS spectrum quality assessment of shotgun proteomics data sets using high-resolution mass spectrometry. Anal Chem 79:5620-5632.

Ibarrola N, Kalume DE, Gronborg M, Iwahori A, Pandey A. 2003. A proteomic approach for quantitation of phosphorylation using stable isotope labeling in cell culture. Anal Chem 75:6043-6049.

Ibarrola N, Molina H, Iwahori A, Pandey A. 2004. A novel proteomic approach for specific identification of tyrosine kinase substrates using [13C]tyrosine. J Biol Chem 279:15805-15813.

Ishihama Y. 2005a. Exponentially modified protein abundance index (emPAI) for estimation of absolute protein amount in proteomics by the number of sequenced peptides per protein. Mol Cell Proteomics 4(9):1265-1272.

Ishihama Y. 2005b. Quantitative mouse brain proteomics using culturederived isotope tags as internal standards. Nat Biotechnol 23:617621.

Jain K. 2004. Role of pharmacoproteomics in the development of personalized medicine. Pharmacogenomics 5:331-336.
Janecki DJ, Bemis KG, Tegeler TJ, Sanghani PC, Zhai L, Hurley TD, Bosron WF, Wang M. 2007. A multiple reaction monitoring method for absolute quantification of the human liver alcohol dehydrogenase ADH1C1 isoenzyme. Anal Biochem 369:18-26.

Jiang X-S, Dai J, Sheng Q-H, Zhang L, Xia Q-C, Wu J-R, Zeng R. 2005. A comparative proteomic strategy for subcellular proteome research. Mol Cell Proteomics 4:12-34.

Johansson C, Samskog J, Sundström L, Wadensten H, Björkesten L, Flensburg J. 2006. Differential expression analysis of Escherichia coli proteins using a novel software for relative quantitation of LCMS/MS data. Proteomics 6:4475-4485.

Jorge I, Navarro P, Martínez-Acedo P, Núñez E, Serrano H, Alfranca A, Redondo JM, Vázquez J. 2009. Statistical model to analyze quantitative proteomics data obtained by $18 \mathrm{O} / 16 \mathrm{O}$ labeling and linear ion trap mass spectrometry. Mol Cell Proteomics 8:1130-1149.

Kamper P, Ludvigsen M, Bendix K, Hamilton-Dutoit S, Rabinovich GA, Møller MB, Nyengaard JR, Honoré B, d'Amore F. 2011. Proteomic analysis identifies galectin-1 as a predictive biomarker for relapsed/ refractory disease in classical Hodgkin lymphoma. Blood 117(24): 6638-6649.

Kandasamy K, Keerthikumar S, Goel R, Mathivanan S, Patankar N, Shafreen B, Renuse S, Pawar H, Ramachandra YL, Acharya PK, Ranganathan P, Chaerkady R, Keshava Prasad TS, Pandey A. 2009. Human proteinpedia: A unified discovery resource for proteomics research. Nucleic Acids Res 37:D773-D781.

Kanehisa M, Araki M, Goto S, Hattori M, Hirakawa M, Itoh M, Katayama T, Kawashima S, Okuda S, Tokimatsu T, Yamanishi Y. 2008. KEGG for linking genomes to life and the environment. Nucleic Acids Res 36:D480-D484.

Karp NA, Huber W, Sadowski PG, Charles PD, Hester SV, Lilley KS. 2010. Addressing accuracy and precision issues in iTRAQ quantitation. Mol Cell Proteomics 9:1885-1897.

Keidel E-M, Ribitsch D, Lottspeich F. 2010. Equalizer technology-Equal rights for disparate beads. Proteomics 10:2089-2098.

Keller A, Eng J, Zhang N, Li X-j, Aebersold R. 2005. A uniform proteomics MS/MS analysis platform utilizing open XML file formats. Mol Syst Biol 1:2005.0017.

Kelly-Spratt KS, Kasarda AE, Igra M, Kemp CJ. 2008. A mouse model repository for cancer biomarker discovery. J Proteome Res 7:36133618 .

Keshishian H, Addona T, Burgess M, Kuhn E, Carr SA. 2007. Quantitative, multiplexed assays for low abundance proteins in plasma by targeted mass spectrometry and stable isotope dilution. Mol Cell Proteomics 6:2212-2229.

Keshishian H, Addona T, Burgess M, Mani DR, Shi X, Kuhn E, Sabatine MS, Gerszten RE, Carr SA. 2009. Quantification of cardiovascular biomarkers in patient plasma by targeted mass spectrometry and stable isotope dilution. Mol Cell Proteomics 8:2339-2349.

Khositseth S, Pisitkun T, Slentz DH, Wang G, Hoffert JD, Knepper MA, Yu M-J. 2011. Quantitative protein and mRNA profiling shows selective post-transcriptional control of protein expression by vasopressin in kidney cells. Mol Cell Proteomics 10(1):M110.004036.

Kirkpatrick DS, Gerber SA, Gygi SP. 2005. The absolute quantification strategy: A general procedure for the quantification of proteins and post-translational modifications. Methods 35:265-273.

Kito K, Ota K, Fujita T, Ito T. 2007. A synthetic protein approach toward accurate mass spectrometric quantification of component stoichiometry of multiprotein complexes. J Proteome Res 6:792-800.

Kiyonami R, Schoen A, Prakash A, Peterman S, Zabrouskov V, Picotti P, Aebersold R, Huhmer A, Domon B. 2011. Increased selectivity, analytical precision, and throughput in targeted proteomics. Mol Cell Proteomics 10(2):M110.002931.

Köcher T, Pichler P, Schutzbier M, Stingl C, Kaul A, Teucher N, Hasenfuss G, Penninger JM, Mechtler K. 2009. High precision quantitative proteomics using iTRAQ on an LTQ Orbitrap: A new mass spectrometric method combining the benefits of all. J Proteome Res 8: 4743-4752. 
Kolch W, Mischak H, Pitt AR. 2005. The molecular make-up of a tumour: Proteomics in cancer research. Clin Sci 108:369-383.

Krijgsveld J, Ketting RF, Mahmoudi T, Johansen J, Artal-Sanz M, Verrijzer CP, Plasterk RHA, Heck AJR. 2003. Metabolic labeling of C. elegans and D. melanogaster for quantitative proteomics. Nat Biotech 21:927-931.

Krokhin OV, Craig R, Spicer V, Ens W, Standing KG, Beavis RC, Wilkins JA. 2004. An improved model for prediction of retention times of tryptic peptides in ion pair reversed-phase HPLC. Mol Cell Proteomics 3:908-919.

Krüger M, Moser M, Ussar S, Thievessen I, Luber CA, Forner F, Schmidt S, Zanivan S, Fässler R, Mann M. 2008. SILAC mouse for quantitative proteomics uncovers kindlin-3 as an essential factor for red blood cell function. Cell 134:353-364.

Kuhn E. 2004. Quantification of C-reactive protein in the serum of patients with rheumatoid arthritis using multiple reaction monitoring mass spectrometry and 13C-labeled peptide standards. Proteomics 4:1175-1186

Kuhn E, Addona T, Keshishian H, Burgess M, Mani DR, Lee RT, Sabatine MS, Gerszten RE, Carr SA. 2009. Developing multiplexed assays for troponin I and interleukin-33 in plasma by peptide immunoaffinity enrichment and targeted mass spectrometry. Clin Chem 55:11081117.

Kulasingam V, Diamandis EP. 2007. Proteomics analysis of conditioned media from three breast cancer cell lines. Mol Cell Proteomics 6:1997-2011.

Kuster B, Schirle M, Mallick P, Aebersold R. 2005. Scoring proteomes with proteotypic peptide probes. Nat Rev Mol Cell Biol 6:577583.

Kuzyk MA, Smith D, Yang J, Cross TJ, Jackson AM, Hardie DB, Anderson NL, Borchers CH. 2009. Multiple reaction monitoring-based, multiplexed, absolute quantitation of 45 proteins in human plasma. Mol Cell Proteomics 8:1860-1877.

Lacerda CMR, Xin L, Rogers I, Reardon KF. 2008. Analysis of iTRAQ data using mascot and peaks quantification algorithms. Briefings Funct Genomics Proteomics 7:119-126.

Laderas T, Bystrom C, McMillen D, Fan G, McWeeney S. 2007. TandTRAQ: An open-source tool for integrated protein identification and quantitation. Bioinformatics 23:3394-3396.

Lai KKY, Kolippakkam D, Beretta L. 2008. Comprehensive and quantitative proteome profiling of the mouse liver and plasma. Hepatology 47:1043-1051.

Lange V, Malmström JA, Didion J, King NL, Johansson BP, Schäfer J, Rameseder J, Wong C-H, Deutsch EW, Brusniak M-Y, Bühlmann P, Björck L, Domon B, Aebersold R. 2008a. Targeted Quantitative analysis of streptococcus pyogenes virulence factors by multiple reaction monitoring. Mol Cell Proteomics 7:1489-1500.

Lange V, Picotti P, Domon B, Aebersold R. 2008b. Selected reaction monitoring for quantitative proteomics: A tutorial. Mol Syst Biol 4:222.

Lau E, Lam MPY, Siu SO, Kong RPW, Chan WL, Zhou Z, Huang J, Lo C, Chu IK. 2011. Combinatorial use of offline SCX and online RPRP liquid chromatography for iTRAQ-based quantitative proteomics applications. Mol BioSyst 7:1399-1408.

Lee H-J, Na K, Kwon M-S, Kim H, Kim KS, Paik Y-K. 2009. Quantitative analysis of phosphopeptides in search of the disease biomarker from the hepatocellular carcinoma specimen. Proteomics 9:33953408

Lee CF, Griffiths S, Rodríguez-Suárez E, Pierce A, Unwin RD, Jaworska E, Evans CA, Gaskell SJ, Whetton AD. 2010. Assessment of downstream effectors of BCR/ABL protein tyrosine kinase using combined proteomic approaches. Proteomics 10:3321-3342.

Lee B, Lopez-Ferrer D, Kim BC, Na HB, Park YI, Weitz KK, Warner MG, Hyeon T, Lee S-W, Smith RD, Kim J. 2011. Rapid and efficient protein digestion using trypsin-coated magnetic nanoparticles under pressure cycles. Proteomics 11:309-318.

Leivonen S-K, Rokka A, Östling P, Kohonen P, Corthals GL, Kallioniemi O , Perälä M . 2012. Identification of miR-193b targets in breast cancer cells and systems biological analysis of their functional impact. Mol Cell Proteomics 10(7):M110.005322.

Leung WKC, Ching AKK, Chan AWH, Poon TCW, Mian H, Wong AST, To KF, Wong N. 2011. A novel interplay between oncogenic PFTK1 protein kinase and tumor suppressor TAGLN2 in the control of liver cancer cell motility. Oncogene 3; 30(44):4464-4475.

Li X-j, Yi EC, Kemp CJ, Zhang H, Aebersold R. 2005. A software suite for the generation and comparison of peptide arrays from sets of data collected by liquid chromatography-mass spectrometry. Mol Cell Proteomics 4:1328-1340.

Li G-Z, Vissers JPC, Silva JC, Golick D, Gorenstein MV, Geromanos SJ. 2009. Database searching and accounting of multiplexed precursor and product ion spectra from the data independent analysis of simple and complex peptide mixtures. Proteomics 9:1696-1719.

Lin W-T, Hung W-N, Yian Y-H, Wu K-P, Han C-L, Chen Y-R, Chen Y-J, Sung T-Y, Hsu W-L. 2006. Multi-Q: A fully automated tool for multiplexed protein quantitation. J Proteome Res 5:2328-2338.

Liu H, Sadygov RG, Yates JR. 2004. A model for random sampling and estimation of relative protein abundance in shotgun proteomics. Anal Chem 76:4193-4201.

Lopez MF, Kuppusamy R, Sarracino DA, Prakash A, Athanas M, Krastins B, Rezai T, Sutton JN, Peterman S, Nicolaides K. 2010. Mass spectrometric discovery and selective reaction monitoring (SRM) of putative protein biomarker candidates in first trimester trisomy 21 maternal serum. J Proteome Res 10(1):133-142.

López-Ferrer D, Petritis K, Robinson EW, Hixson KK, Tian Z, Lee JH, Lee S-W, Tolić N, Weitz KK, Belov ME, Smith RD, Paša-Tolić L. 2011. Pressurized pepsin digestion in proteomics. Mol Cell Proteomics 10(2):M110.001479.

Lu P, Vogel C, Wang R, Yao X, Marcotte EM. 2007. Absolute protein expression profiling estimates the relative contributions of transcriptional and translational regulation. Nat Biotech 25:117-124.

Luethy R, Kessner DE, Katz JE, MacLean B, Grothe R, Kani K, Faça V, Pitteri S, Hanash S, Agus DB, Mallick P. 2008. Precursor-ion mass re-estimation improves peptide identification on hybrid instruments. J Proteome Res 7:4031-4039.

Ma D, Chan MK, Lockstone HE, Pietsch SR, Jones DNC, Cilia J, Hill MD, Robbins MJ, Benzel IM, Umrania Y, Guest PC, Levin Y, Maycox PR, Bahn S. 2009. Antipsychotic treatment alters protein expression associated with presynaptic function and nervous system development in rat frontal cortex. J Proteome Res 8:3284-3297.

MacCoss MJ, Wu CC, Liu H, Sadygov R, Yates JR. 2003. A correlation algorithm for the automated quantitative analysis of shotgun proteomics data. Anal Chem 75:6912-6921.

Mallick P, Schirle M, Chen SS, Flory MR, Lee H, Martin D, Ranish J, Raught B, Schmitt R, Werner T, Kuster B, Aebersold R. 2007. Computational prediction of proteotypic peptides for quantitative proteomics. Nat Biotech 25:125-131.

Malmstrom J, Beck M, Schmidt A, Lange V, Deutsch EW, Aebersold R. 2009. Proteome-wide cellular protein concentrations of the human pathogen Leptospira interrogans. Nature 460:762-765.

Mao L, Yang P, Hou S, Li F, Kijlstra A. 2011. Label-free proteomics reveals decreased expression of CD18 and AKNA in peripheral $\mathrm{CD}^{+} \mathrm{T}$ cells from patients with Vogt-Koyanagi-Harada syndrome. PLOS ONE 6:e14616.

Martens L, Hermjakob H, Jones P, Adamski M, Taylor C, States D, Gevaert K, Vandekerckhove J, Apweiler R. 2005. PRIDE: The proteomics identifications database. Proteomics 5:3537-3545.

Martin K, Steinberg TH, Cooley LA, Gee KR, Beechem JM, Patton WF. 2003. Quantitative analysis of protein phosphorylation status and protein kinase activity on microarrays using a novel fluorescent phosphorylation sensor dye. Proteomics 3:1244-1255.

Matharoo-Ball B, Ball G, Rees R. 2007. Clinical proteomics: Discovery of cancer biomarkers using mass spectrometry and bioinformatics approaches-A prostate cancer perspective. Vaccine 25:B110-B121.

Matthiesen R, Trelle MB, Højrup P, Bunkenborg J, Jensen ON. 2005. VEMS 3.0: Algorithms and computational tools for tandem mass 
spectrometry based identification of post-translational modifications in proteins. J Proteome Res 4:2338-2347.

Maziarz M, Chung C, Drucker DJ, Emili A. 2005. Integrating global proteomic and genomic expression profiles generated from islet $\alpha$ cells. Mol Cell Proteomics 4:458-474.

McAlister GC, Berggren WT, Griep-Raming J, Horning S, Makarov A, Phanstiel D, Stafford G, Swaney DL, Syka JEP, Zabrouskov V, Coon JJ. 2008. A proteomics grade electron transfer dissociation-enabled hybrid linear ion trap-orbitrap mass spectrometer. J Proteome Res 7:3127-3136.

McAlister GC, Phanstiel DH, Brumbaugh J, Westphall MS, Coon JJ. 2011. Higher-energy collision-activated dissociation without a dedicated collision cell. Mol Cell Proteomics 10(5):O111.009456.

Mi H, Lazareva-Ulitsky B, Loo R, Kejariwal A, Vandergriff J, Rabkin S, Guo N, Muruganujan A, Doremieux O, Campbell MJ, Kitano H, Thomas PD. 2005. The PANTHER database of protein families, subfamilies, functions and pathways. Nucleic Acids Res 33:D284D288.

Michalski A, Damoc E, Hauschild J-P, Lange O, Wieghaus A, Makarov A, Nagaraj N, Cox J, Mann M, Horning S. 2011. Mass spectrometry-based proteomics using Q Exactive, a high-performance benchtop quadrupole Orbitrap mass spectrometer. Mol Cell Proteomics 10(9):M111.011015.

Millioni R, Tolin S, Puricelli L, Sbrignadello S, Fadini GP, Tessari P, Arrigoni G. 2011. High abundance proteins depletion vs low abundance proteins enrichment: Comparison of methods to reduce the plasma proteome complexity. PLoS ONE 6:e19603.

Mirgorodskaya OA. 2000. Quantitation of peptides and proteins by matrix-assisted laser desorption/ionization mass spectrometry using (18)O-labeled internal standards. Rapid Commun Mass Spectrom 14:1226-1232.

Mirza SP, Greene AS, Olivier M. 2008. ${ }^{18}$ O labeling over a coffee break: A rapid strategy for quantitative proteomics. J Proteome Res 7:3042-3048.

Mirzaei H, McBee JK, Watts J, Aebersold R. 2008. Comparative evaluation of current peptide production platforms used in absolute quantification in proteomics. Mol Cell Proteomics 7:813-823.

Mischerikow N, van Nierop P, Li KW, Bernstein H-G, Smit AB, Heck AJR, Altelaar AFM. 2010. Gaining efficiency by parallel quantification and identification of iTRAQ-labeled peptides using HCD and decision tree guided CID/ETD on an LTQ Orbitrap. Analyst 135:2643-2652.

Miseta A, Csutora P. 2000. Relationship between the occurrence of cysteine in proteins and the complexity of organisms. Mol Biol Evol 17:1232-1239.

Miyagi M, Rao KCS. 2007. Proteolytic ${ }^{18}$ O-labeling strategies for quantitative proteomics. Mass Spectrom Rev 26:121-136.

Mortensen P, Gouw JW, Olsen JV, Ong S-E, Rigbolt KTG, Bunkenborg J, Cox J, Jr., Foster LJ, Heck AJR, Blagoev B, Andersen JS, Mann M. 2009. MSQuant, an open source platform for mass spectrometrybased quantitative proteomics. J Proteome Res 9:393-403.

Mueller LN, Brusniak M-Y, Mani DR, Aebersold R. 2008. An assessment of software solutions for the analysis of mass spectrometry based quantitative proteomics data. J Proteome Res 7:51-61.

Müller C, Schäfer P, Störtzel M, Vogt S, Weinmann W. 2002. Ion suppression effects in liquid chromatography-electrospray-ionisation transport-region collision induced dissociation mass spectrometry with different serum extraction methods for systematic toxicological analysis with mass spectra libraries. J Chromatogr B 773:47-52.

Murakoshi Y, Honda K, Sasazuki S, Ono M, Negishi A, Matsubara J, Sakuma T, Kuwabara H, Nakamori S, Sata N, Nagai H, Ioka T, Okusaka T, Kosuge T, Shimahara M, Yasunami Y, Ino Y, Tsuchida A, Aoki T, Tsugane S, Yamada T. 2011. Plasma biomarker discovery and validation for colorectal cancer by quantitative shotgun mass spectrometry and protein microarray. Cancer Sci 102:630-638

Nakamura T, Dohmae N, Takio K. 2004. Characterization of a digested protein complex with quantitative aspects: An approach based on accurate mass chromatographic analysis with Fourier transform-ion cyclotron resonance mass spectrometry. Proteomics 4:2558-2566.

Nicol GR, Han M, Kim J, Birse CE, Brand E, Nguyen A, Mesri M, FitzHugh W, Kaminker P, Moore PA, Ruben SM, He T. 2008. Use of an immunoaffinity-mass spectrometry-based approach for the quantification of protein biomarkers from serum samples of lung cancer patients. Mol Cell Proteomics 7:1974-1982.

Niggeweg R, Köcher T, Gentzel M, Buscaino A, Taipale M, Akhtar A, Wilm M. 2006. A general precursor ion-like scanning mode on quadrupole-TOF instruments compatible with chromatographic separation. Proteomics 6:41-53.

Nirmalan N, Sims PFG, Hyde JE. 2004. Quantitative proteomics of the human malaria parasite Plasmodium falciparum and its application to studies of development and inhibition. Mol Microbiol 52:11871199.

Oda Y, Huang K, Cross FR, Cowburn D, Chait BT. 1999. Accurate quantitation of protein expression and site-specific phosphorylation. Proc Natl Acad Sci USA 96:6591-6596.

Old WM, Meyer-Arendt K, Aveline-Wolf L, Pierce KG, Mendoza A, Sevinsky JR, Resing KA, Ahn NG. 2005. Comparison of label-free methods for quantifying human proteins by shotgun proteomics. Mol Cell Proteomics 4:1487-1502.

Olsen JV, de Godoy LMF, Li G, Macek B, Mortensen P, Pesch R, Makarov A, Lange O, Horning S, Mann M. 2005. Parts per million mass accuracy on an orbitrap mass spectrometer via lock mass injection into a C-trap. Mol Cell Proteomics 4:2010-2021.

Olsen JV, Macek B, Lange O, Makarov A, Horning S, Mann M. 2007. Higher-energy C-trap dissociation for peptide modification analysis. Nat Methods 4:709-712.

Ong SE. 2002. Stable isotope labeling by amino acids in cell culture, SILAC, as a simple and accurate approach to expression proteomics. Mol Cell Proteomics 1:376-386.

Ong S-E, Mann M. 2005. Mass spectrometry-based proteomics turns quantitative. Nat Chem Biol 1:252-262.

Ong SE, Kratchmarova I, Mann M. 2003. Properties of 13C-substituted arginine in stable isotope labeling by amino acids in cell culture (SILAC). J Proteome Res 2:173-181.

Ong SE, Mittler G, Mann M. 2004. Identifying and quantifying in vivo methylation sites by heavy methyl SILAC. Nat Methods 1:119-126.

Ostroff RM, Bigbee WL, Franklin W, Gold L, Mehan M, Miller YE, Pass HI, Rom WN, Siegfried JM, Stewart A, Walker JJ, Weissfeld JL, Williams S, Zichi D, Brody EN. 2010. Unlocking biomarker discovery: Large scale application of aptamer proteomic technology for early detection of lung cancer. PLoS ONE 5:e15003.

Ow SY, Salim M, Noirel J, Evans C, Rehman I, Wright PC. 2009. iTRAQ underestimation in simple and complex mixtures: "The good, the bad and the ugly". J Proteome Res 8:5347-5355.

Ow SY, Noirel J, Salim M, Evans C, Watson R, Wright PC. 2010. Balancing robust quantification and identification for iTRAQ: Application of UHR-ToF MS. Proteomics 10:2205-2213.

Park K-S, Mohapatra DP, Misonou H, Trimmer JS. 2006. Graded regulation of the Kv2.1 potassium channel by variable phosphorylation. Science 313:976-979.

Park SK, Venable JD, Xu T, Yates JR. 2008. A quantitative analysis software tool for mass spectrometry-based proteomics. Nat Methods 5:319-322.

Picotti P, Lam H, Campbell D, Deutsch EW, Mirzaei H, Ranish J, Domon B, Aebersold R. 2008. A database of mass spectrometric assays for the yeast proteome. Nat Methods 5:913-914.

Picotti P, Bodenmiller B, Mueller LN, Domon B, Aebersold R. 2009. Full dynamic range proteome analysis of $S$. cerevisiae by targeted proteomics. Cell 138:795-806.

Pierce A, Unwin RD, Evans CA, Griffiths S, Carney L, Zhang L, Jaworska E, Lee C-F, Blinco D, Okoniewski MJ, Miller CJ, Bitton DA, Spooncer E, Whetton AD. 2008. Eight-channel iTRAQ enables comparison of the activity of six leukemogenic tyrosine kinases. Mol Cell Proteomics 7:853-863. 
Pitarch A, Nombela C, Gil C. 2011. Prediction of the clinical outcome in invasive candidiasis patients based on molecular fingerprints of five anti-candida antibodies in serum. Mol Cell Proteomics 10(1):M110. 004010 .

Prakash C, Shaffer CL, Nedderman A. 2007. Analytical strategies for identifying drug metabolites. Mass Spectrom Rev 26:340-369.

Prakash A, Tomazela DM, Frewen B, MacLean B, Merrihew G, Peterman S, MacCoss MJ. 2009. Expediting the development of targeted SRM assays: Using data from shotgun proteomics to automate method development. J Proteome Res 8:2733-2739.

Pratt JM, Petty J, Riba-Garcia I, Robertson DHL, Gaskell SJ, Oliver SG, Beynon RJ. 2002. Dynamics of protein turnover, a missing dimension in proteomics. Mol Cell Proteomics 1:579-591.

Pratt JM, Simpson DM, Doherty MK, Rivers J, Gaskell SJ, Beynon RJ. 2006. Multiplexed absolute quantification for proteomics using concatenated signature peptides encoded by QconCAT genes. Nat Protoc 1:1029-1043.

Pritsker M, Lemischka IR. 2006. Alternative splicing increases complexity of stem cell transcriptome. Cell Cycle 5:347-351.

Qualtieri A, Urso E, Pera ML, Sprovieri T, Bossio S, Gambardella A, Quattrone A. 2010. Proteomic profiling of cerebrospinal fluid in Creutzfeldt-Jakob disease. Expert Rev Proteomics 7:907-917.

Rabilloud T. 2002. Two-dimensional gel electrophoresis in proteomics: Old, old fashioned, but it still climbs up the mountains. Proteomics 2:3-10.

Radulovic D, Jelveh S, Ryu S, Hamilton TG, Foss E, Mao Y, Emili A. 2004. Informatics platform for global proteomic profiling and biomarker discovery using liquid chromatography-tandem mass spectrometry. Mol Cell Proteomics 3:984-997.

Raijmakers R, Neerincx P, Mohammed S, Heck AJR. 2010. Cleavage specificities of the brother and sister proteases Lys-C and Lys-N. Chem Commun 46:8827-8829.

Rajapakse JC, Duan K-B, Kiang Yeo W. 2005. Proteomic cancer classification with mass spectrometry data. Am J Pharmacogenomics 5: 281-292.

Ramos-Fernández A, López-Ferrer D, Vázquez J. 2007. Improved method for differential expression proteomics using trypsin-catalyzed ${ }^{18} \mathrm{O}$ labeling with a correction for labeling efficiency. Mol Cell Proteomics 6:1274-1286.

Rao KCS, Carruth RT, Miyagi M. 2005. Proteolytic 180 labeling by peptidyl-Lys metalloendopeptidase for comparative proteomics. J Proteome Res 4:507-514.

Rappsilber J, Ryder U, Lamond AI, Mann M. 2002. Large-scale proteomic analysis of the human spliceosome. Genome Res 12:1231-1245.

Richardson MR, Lai X, Witzmann FA, Yoder MC. 2010. Venous and arterial endothelial proteomics: Mining for markers and mechanisms of endothelial diversity. Expert Rev Proteomics 7:823-831.

Rifai N, Gillette MA, Carr SA. 2006. Protein biomarker discovery and validation: The long and uncertain path to clinical utility. Nat Biotech 24:971-983.

Righetti PG, Boschetti E. 2008. The ProteoMiner and the FortyNiners: Searching for gold nuggets in the proteomic arena. Mass Spectrom Rev 27:596-608.

Righetti PG, Castagna A, Antonioli P, Boschetti E. 2005. Prefractionation techniques in proteome analysis: The mining tools of the third millennium. Electrophoresis 26:297-319.

Righetti PG, Boschetti E, Lomas L, Citterio A. 2006. Protein Equalizer ${ }^{\mathrm{TM}}$ Technology: The quest for a "democratic proteome". Proteomics 6:3980-3992.

Righetti PG, Boschetti E, Kravchuk AV, Fasoli E. 2010. The proteome buccaneers: How to unearth your treasure chest via combinatorial peptide ligand libraries. Expert Rev Proteomics 7:373-385.

Rivers J, Simpson DM, Robertson DHL, Gaskell SJ, Beynon RJ. 2007. Absolute multiplexed quantitative analysis of protein expression during muscle development using QconCAT. Mol Cell Proteomics 6:1416-1427.
Rodríguez-Suárez E, Gubb E, Alzueta IF, Falcón-Pérez JM, Amorim A, Elortza F, Matthiesen R. 2010. Virtual expert mass spectrometrist: iTRAQ tool for database-dependent search, quantitation and result storage. Proteomics 10:1545-1556.

Ross PL, Huang YN, Marchese JN, Williamson B, Parker K, Hattan S, Khainovski N, Pillai S, Dey S, Daniels S, Purkayastha S, Juhasz P, Martin S, Bartlet-Jones M, He F, Jacobson A, Pappin DJ. 2004. Multiplexed protein quantitation in Saccharomyces cerevisiae using amine-reactive isobaric tagging reagents. Mol Cell Proteomics 3:1154-1169.

Ruppen I, Grau L, Orenes-Piñero E, Ashman K, Gil M, Algaba F, Bellmunt J, Sánchez-Carbayo M. 2010. Differential protein expression profiling by iTRAQ-two-dimensional LC-MS/MS of human bladder cancer EJ138 cells transfected with the metastasis suppressor KiSS-1 gene. Mol Cell Proteomics 9:2276-2291.

Russell WK, Park Z-Y, Russell DH. 2001. Proteolysis in mixed organicAqueous solvent systems: Applications for peptide mass mapping using mass spectrometry. Anal Chem 73:2682-2685.

Sandra K, Verleysen K, Labeur C, Vanneste L, D’Hondt F, Thomas G, Kas K, Gevaert K, Vandekerckhove J, Sandra P. 2007. Combination of COFRADIC and high temperature-Extended column length conventional liquid chromatography: A very efficient way to tackle complex protein samples, such as serum. J Sep Sci 30:658668.

Sardiu ME, Washburn MP. 2010. Enriching quantitative proteomics with SIN. Nat Biotech 28:40-42.

Sardiu ME, Cai Y, Jin J, Swanson SK, Conaway RC, Conaway JW, Florens L, Washburn MP. 2008. Probabilistic assembly of human protein interaction networks from label-free quantitative proteomics. Proc Natl Acad Sci 105:1454-1459.

Savitski M, Fischer F, Mathieson T, Sweetman G, Lang M, Bantscheff M. 2010. Targeted data acquisition for improved reproducibility and robustness of proteomic mass spectrometry assays. J Am Soc Mass Spectrom 21:1668-1679.

Schulze WX, Mann M. 2004. A novel proteomic screen for peptideprotein interactions. J Biol Chem 279:10756-10764.

Schwamborn K, Gaisa NT, Henkel C. 2010. Tissue and serum proteomic profiling for diagnostic and prognostic bladder cancer biomarkers. Expert Rev Proteomics 7:897-906.

Searle BC. 2010. Scaffold: A bioinformatic tool for validating MS/MSbased proteomic studies. Proteomics 10:1265-1269.

Sela I, Milman Krentsis I, Shlomai Z, Sadeh M, Dabby R, Argov Z, Ben-Bassat H, Mitrani-Rosenbaum S. 2011. The proteomic profile of hereditary inclusion body myopathy. PLoS ONE 6:e16334.

Sevinsky JR, Brown KJ, Cargile BJ, Bundy JL, Stephenson JL. 2007. Minimizing back exchange in $18 \mathrm{O} / 16 \mathrm{O}$ quantitative proteomics experiments by incorporation of immobilized trypsin into the initial digestion step. Anal Chem 79:2158-2162.

Shadforth I, Dunkley T, Lilley K, Bessant C. 2005. i-Tracker: For quantitative proteomics using iTRAQTM. BMC Genomics 6:145.

Sherman J, McKay MJ, Ashman K, Molloy MP. 2009. How specific is my SRM?: The issue of precursor and product ion redundancy. Proteomics 9:1120-1123.

Shi Y, Chan DW, Jung SY, Malovannaya A, Wang Y, Qin J. 2011. A dataset of human endogenous ubiquitination sites. Mol Cell Proteomics 10(5):M110.002089.

Shinkawa T, Taoka M, Yamauchi Y, Ichimura T, Kaji H, Takahashi N, Isobe T. 2005. STEM: A software tool for large-scale proteomic data analyses. J Proteome Res 4:1826-1831.

Shinoda K, Tomita M, Ishihama Y. 2010. emPAI Calc-For the estimation of protein abundance from large-scale identification data by liquid chromatography-tandem mass spectrometry. Bioinformatics 26:576577.

Shirran SL, Botting CH. 2010. A comparison of the accuracy of iTRAQ quantification by nLC-ESI MSMS and nLC-MALDI MSMS methods. J Proteomics 73:1391-1403. 
Silva JC, Denny R, Dorschel CA, Gorenstein M, Kass IJ, Li G-Z, McKenna T, Nold MJ, Richardson K, Young P, Geromanos S. 2005. Quantitative proteomic analysis by accurate mass retention time pairs. Anal Chem 77:2187-2200.

Silva JC, Denny R, Dorschel C, Gorenstein MV, Li G-Z, Richardson K, Wall D, Geromanos SJ. 2006a. Simultaneous qualitative and quantitative analysis of the Escherichia coli proteome. Mol Cell Proteomics 5:589-607.

Silva JC, Gorenstein MV, Li G-Z, Vissers JPC, Geromanos SJ. $2006 \mathrm{~b}$. Absolute quantification of proteins by LCMSE. Mol Cell Proteomics 5:144-156.

Silvestrini F, Lasonder E, Olivieri A, Camarda G, van Schaijk B, Sanchez M, Younis Younis S, Sauerwein R, Alano P. 2010. Protein export marks the early phase of gametocytogenesis of the human malaria parasite Plasmodium falciparum. Mol Cell Proteomics 9:1437-1448.

Soufi B, Kumar C, Gnad F, Mann M, Mijakovic I, Macek B. 2010. Stable isotope labeling by amino acids in cell culture (SILAC) applied to quantitative proteomics of Bacillus subtilis. J Proteome Res 9:36383646.

Staes A, Demol H, Van Damme J, Martens L, Vandekerckhove J, Gevaert K. 2004. Global differential non-gel proteomics by quantitative and stable labeling of tryptic peptides with oxygen-18. J Proteome Res 3:786-791

Stahl-Zeng J, Lange V, Ossola R, Eckhardt K, Krek W, Aebersold R, Domon B. 2007. High sensitivity detection of plasma proteins by multiple reaction monitoring of $\mathrm{N}$-glycosites. Mol Cell Proteomics 6:1809-1817.

Stapels M, Piper C, Yang T, Li M, Stowell C, Xiong Z-g, Saugstad J, Simon RP, Geromanos S, Langridge J, Lan J-q, Zhou A. 2010. Polycomb group proteins as epigenetic mediators of neuroprotection in ischemic tolerance. Sci Signal 3:ra15.

Steinberg TH, Agnew BJ, Gee KR, Leung W-Y, Goodman T, Schulenberg B, Hendrickson J, Beechem JM, Haugland RP, Patton WF. 2003. Global quantitative phosphoprotein analysis using Multiplexed Proteomics technology. Proteomics 3:1128-1144.

Stemmann O, Zou H, Gerber SA, Gygi SP, Kirschner MW. 2001. Dual inhibition of sister chromatid separation at metaphase. Cell 107:715726.

Strader MB, Tabb DL, Hervey WJ, Pan C, Hurst GB. 2005. Efficient and specific trypsin digestion of microgram to nanogram quantities of proteins in organic-aqueous solvent systems. Anal Chem 78:125134.

Surinova S, Schiess R, Hüttenhain R, Cerciello F, Wollscheid B, Aebersold R. 2010. On the development of plasma protein biomarkers. J Proteome Res 10:5-16.

Sury MD, Chen J-X, Selbach M. 2010. The SILAC fly allows for accurate protein quantification in vivo. Mol Cell Proteomics 9:2173-2183.

Syka JE. 2004. Novel linear quadrupole ion trap/FT mass spectrometer: Performance characterization and use in the comparative analysis of histone $\mathrm{H} 3$ post-translational modifications. J Proteome Res 3:621626.

Tang K, Page JS, Smith RD. 2004. Charge competition and the linear dynamic range of detection in electrospray ionization mass spectrometry. J Am Soc Mass Spectrom 15:1416-1423.

Tang H, Arnold RJ, Alves P, Xun Z, Clemmer DE, Novotny MV, Reilly JP, Radivojac P. 2006. A computational approach toward label-free protein quantification using predicted peptide detectability. Bioinformatics 22:e481-e488.

Taouatas N, Heck AJR, Mohammed S. 2010. Evaluation of metalloendopeptidase Lys-N protease performance under different sample handling conditions. J Proteome Res 9:4282-4288.

Taussig MJ, Stoevesandt O, Borrebaeck CAK, Bradbury AR, Cahill D, Cambillau C, de Daruvar A, Dubel S, Eichler J, Frank R, Gibson TJ, Gloriam D, Gold L, Herberg FW, Hermjakob H, Hoheisel JD, Joos TO, Kallioniemi O, Koegl M, Konthur Z, Korn B, Kremmer E, Krobitsch S, Landegren U, van der Maarel S, McCafferty J, Muyldermans S, Nygren P-A, Palcy S, Pluckthun A, Polic B, Przybylski M,
Saviranta P, Sawyer A, Sherman DJ, Skerra A, Templin M, Ueffing M, Uhlen M. 2007. ProteomeBinders: Planning a European resource of affinity reagents for analysis of the human proteome. Nat Methods 4:13-17.

Thakur SS, Geiger T, Chatterjee B, Bandilla P, Fröhlich F, Cox J, Mann M. 2011. Deep and highly sensitive proteome coverage by LC-MS/ MS without prefractionation. Mol Cell Proteomics 10(8): M110.003699.

Thompson A. 2003. Tandem mass tags: A novel quantification strategy for comparative analysis of complex protein mixtures by MS/MS. Anal Chem 75:1895-1904.

Tirumalai RS, Chan KC, Prieto DA, Issaq HJ, Conrads TP, Veenstra TD. 2003. Characterization of the low molecular weight human serum proteome. Mol Cell Proteomics 2:1096-1103.

Tjalsma H. 2010. Identification of biomarkers for colorectal cancer through proteomics-based approaches. Expert Rev Proteomics 7: 879-895.

Tops BBJ, Gauci S, Heck AJR, Krijgsveld J. 2009. Worms from Venus and Mars: Proteomics profiling of sexual differences in Caenorhabditis elegans using in vivo $15 \mathrm{~N}$ isotope labeling. J Proteome Res 9:341-351.

Ueda K, Takami S, Saichi N, Daigo Y, Ishikawa N, Kohno N, Katsumata M, Yamane A, Ota M, Sato T-A, Nakamura Y, Nakagawa H. 2010. Development of serum glycoproteomic profiling technique; simultaneous identification of glycosylation sites and site-specific quantification of glycan structure changes. Mol Cell Proteomics 9:1819-1828.

Ünlü M, Morgan ME, Minden JS. 1997. Difference gel electrophoresis. A single gel method for detecting changes in protein extracts. Electrophoresis 18:2071-2077.

Unwin RD, Griffiths JR, Leverentz MK, Grallert A, Hagan IM, Whetton AD. 2005. Multiple reaction monitoring to identify sites of protein phosphorylation with high sensitivity. Mol Cell Proteomics 4:11341144.

Unwin RD, Smith DL, Blinco D, Wilson CL, Miller CJ, Evans CA, Jaworska E, Baldwin SA, Barnes K, Pierce A, Spooncer E, Whetton AD. 2006. Quantitative proteomics reveals posttranslational control as a regulatory factor in primary hematopoietic stem cells. Blood 107: 4687-4694.

Unwin RD, Griffiths JR, Whetton AD. 2009. A sensitive mass spectrometric method for hypothesis-driven detection of peptide post-translational modifications: Multiple reaction monitoring-initiated detection and sequencing (MIDAS). Nat Protoc 4:870-877.

Van Hoof D, Pinkse MWH, Oostwaard DW-V, Mummery CL, Heck AJR, Krijgsveld J. 2007. An experimental correction for arginine-toproline conversion artifacts in SILAC-based quantitative proteomics. Nat Methods 4:677-678.

Vandenbogaert M, Li-Thiao-Té S, Kaltenbach H-M, Zhang R, Aittokallio T, Schwikowski B. 2008. Alignment of LC-MS images, with applications to biomarker discovery and protein identification. Proteomics 8:650-672.

VanGuilder HD, Bixler GV, Kutzler L, Brucklacher RM, Bronson SK, Kimball SR, Freeman WM. 2011. Multi-modal proteomic analysis of retinal protein expression alterations in a rat model of diabetic retinopathy. PLoS ONE 6:e16271.

Visintin I, Feng Z, Longton G, Ward DC, Alvero AB, Lai Y, Tenthorey J, Leiser A, Flores-Saaib R, Yu H, Azori M, Rutherford T, Schwartz PE, Mor G. 2008. Diagnostic markers for early detection of ovarian cancer. Clin Cancer Res 14:1065-1072.

Vissers JPC, Langridge JI, Aerts JMFG. 2007. Analysis and quantification of diagnostic serum markers and protein signatures for Gaucher disease. Mol Cell Proteomics 6:755-766.

Vissers JPC, Pons S, Hulin A, Tissier R, Berdeaux A, Connolly JB, Langridge JI, Geromanos SJ, Ghaleh B. 2009. The use of proteome similarity for the qualitative and quantitative profiling of reperfused myocardium. J Chromatogr B 877:1317-1326.

Vizcaíno JA, Côté R, Reisinger F, Foster JM, Mueller M, Rameseder J, Hermjakob H, Martens L. 2009. A guide to the proteomics identi- 
fications database proteomics data repository. Proteomics 9: 42764283.

Vogelstein B, Kinzler KW. 2004. Cancer genes and the pathways they control. Nat Med 10:789-799.

Voisin SN, Krakovska O, Matta A, DeSouza LV, Romaschin AD, Colgan TJ, Siu KWM. 2011. Identification of novel molecular targets for endometrial cancer using a drill-down LC-MS/MS approach with iTRAQ. PLoS ONE 6:e16352.

Volmer MW, Stühler K, Zapatka M, Schöneck A, Klein-Scory S, Schmiegel W, Meyer HE, Schwarte-Waldhoff I. 2005. Differential proteome analysis of conditioned media to detect Smad4 regulated secreted biomarkers in colon cancer. Proteomics 5:2587-2601.

Voyksner RD, Lee H. 1999. Investigating the use of an octupole ion guide for ion storage and high-pass mass filtering to improve the quantitative performance of electrospray ion trap mass spectrometry. Rapid Commun Mass Spectrom 13:1427-1437.

Walther DM, Mann M. 2011. Accurate quantification of more than 4000 mouse tissue proteins reveals minimal proteome changes during aging. Mol Cell Proteomics 10(2):M110.004523.

Wang YK, Ma Z, Quinn DF, Fu EW. 2001. Inverse ${ }^{18} \mathrm{O}$ labeling mass spectrometry for the rapid identification of marker/target proteins. Anal Chem 73:3742-3750.

Wang W, Zhou H, Lin H, Roy S, Shaler TA, Hill LR, Norton S, Kumar P, Anderle M, Becker CH. 2003. Quantification of proteins and metabolites by mass spectrometry without isotopic labeling or spiked standards. Anal Chem 75:4818-4826.

Wang G, Wu WW, Zeng W, Chou C-L, Shen R-F. 2006. Label-free protein quantification using LC-coupled ion trap or FT mass spectrometry: Reproducibility, linearity, and application with complex proteomes. J Proteome Res 5:1214-1223.

Washburn MP, Wolters D, Yates JR. 2001. Large-scale analysis of the yeast proteome by multidimensional protein identification technology. Nat Biotech 19:242-2247.

Washburn MP, Ulaszek RR, Yates JR. 2003. Reproducibility of quantitative proteomic analyses of complex biological mixtures by multidimensional protein identification technology. Anal Chem 75:5054.

Whiteaker JR, Zhang H, Zhao L, Wang P, Kelly-Spratt KS, Ivey RG, Piening BD, Feng L-C, Kasarda E, Gurley KE, Eng JK, Chodosh LA, Kemp CJ, McIntosh MW, Paulovich AG. 2007. Integrated pipeline for mass spectrometry-based discovery and confirmation of biomarkers demonstrated in a mouse model of breast cancer. J Proteome Res 6:3962-3975.

Wilkins MR. 1996. Progress with proteome projects: Why all proteins expressed by a genome should be identified and how to do it. Biotechnol Genet Eng Rev 13:19-50.

Wiśniewski JR, Zougman A, Mann M. 2009. Combination of FASP and StageTip-based fractionation allows in-depth analysis of the hippocampal membrane proteome. J Proteome Res 8:5674-5678.

Wiśniewski JR, Nagaraj N, Zougman A, Gnad F, Mann M. 2010. Brain phosphoproteome obtained by a FASP-based method reveals plasma membrane protein topology. J Proteome Res 9:3280-3289.

Wolf-Yadlin A, Hautaniemi S, Lauffenburger DA, White FM. 2007. Multiple reaction monitoring for robust quantitative proteomic analysis of cellular signaling networks. Proc Natl Acad Sci 104:5860-5865.

Wright C, Sibani S, Trudgian D, Fischer R, Kessler B, LaBaer J, Bowness P. 2010. Detection of multiple autoantibodies in patients with ankylosing spondylitis using nucleic acid programmable protein arrays. Mol Cell Proteomics M900384-MCP200.

Wright CA, Howles S, Trudgian DC, Kessler BM, Reynard JM, Noble JG, Hamdy FC, Turney BW. 2011. Label-free quantitative proteomics reveals differentially regulated proteins influencing urolithiasis. Mol Cell Proteomics 10(8):M110.005686.

Wu CC, MacCoss MJ, Howell KE, Matthews DE, Yates JRI. 2004. Metabolic labeling of mammalian organisms with stable isotopes for quantitative proteomic analysis. Anal Chem 76:4951-4959.
Xu G, Paige JS, Jaffrey SR. 2010. Global analysis of lysine ubiquitination by ubiquitin remnant immunoaffinity profiling. Nat Biotech 28:868-873.

Yao X, Freas A, Ramirez J, Demirev PA, Fenselau C. 2001. Proteolytic ${ }^{18} \mathrm{O}$ labeling for comparative proteomics: Model studies with two serotypes of adenovirus. Anal Chem 73:2836-2842.

Yao X, Afonso C, Fenselau C. 2003. Dissection of proteolytic ${ }^{18} \mathrm{O}$ labeling: Endoprotease-catalyzed 16O-to-18O exchange of truncated peptide substrates. J Proteome Res 2:147-152.

Yao M, Ma L, Humphreys WG, Zhu M. 2008. Rapid screening and characterization of drug metabolites using a multiple ion monitoring-dependent MS/MS acquisition method on a hybrid triple quadrupolelinear ion trap mass spectrometer. J Mass Spectrom 43:1364-1375.

Yates JR, Eng JK, McCormack AL, Schieltz D. 1995. Method to correlate tandem mass spectra of modified peptides to amino acid sequences in the protein database. Anal Chem 67:1426-1436.

Ying W, Jiang Y, Guo L, Hao Y, Zhang Y, Wu S, Zhong F, Wang J, Shi R, Li D, Wan P, Li X, Wei H, Li J, Wang Z, Xue X, Cai Y, Zhu Y, Qian X, He F. 2006. A dataset of human fetal liver proteome identified by subcellular fractionation and multiple protein separation and identification technology. Mol Cell Proteomics 5:1703-1707.

Yu C-Y, Tsui Y-H, Yian Y-H, Sung T-Y, Hsu W-L. 2007. The Multi-Q web server for multiplexed protein quantitation. Nucleic Acids Res 35:W707-W712.

Yu Y, Shen H, Yu H, Zhong F, Zhang Y, Zhang C, Zhao J, Li H, Chen J, Liu Y, Yang P. 2011. Systematic proteomic analysis of human hepotacellular carcinoma cells reveals molecular pathways and networks involved in metastasis. Mol BioSyst 7:1908-1916.

Zang L, Toy DP, Hancock WS, Sgroi DC, Karger BL. 2004. Proteomic analysis of ductal carcinoma of the breast using laser capture microdissection, LC-MS, and ${ }^{16} \mathrm{O} /{ }^{18} \mathrm{O}$ isotopic labeling. J Proteome Res 3:604-612.

Zhang R, Sioma CS, Wang S, Regnier FE. 2001. Fractionation of isotopically labeled peptides in quantitative proteomics. Anal Chem 73 : 5142-5149.

Zhang H, Li X-j, Martin DB, Aebersold R. 2003. Identification and quantification of N-linked glycoproteins using hydrazide chemistry, stable isotope labeling and mass spectrometry. Nat Biotech 21:660-666.

Zhang B, VerBerkmoes NC, Langston MA, Uberbacher E, Hettich RL, Samatova NF. 2006. Detecting differential and correlated protein expression in label-free shotgun proteomics. J Proteome Res 5:2909_ 2918.

Zhao Y, Denner L, Haidacher S, LeJeune W, Tilton R. 2008. Comprehensive analysis of the mouse renal cortex using two-dimensional HPLC-Tandem mass spectrometry. Proteome Sci 6:15.

Zhu H, Pan S, Gu S, Bradbury EM, Chen X. 2002. Amino acid residue specific stable isotope labeling for quantitative proteomics. Rapid Commun Mass Spectrom 16:2115-2123.

Zolg W. 2006. The proteomic search for diagnostic biomarkers. Mol Cell Proteomics 5:1720-1726.

Zolg JW, Langen H. 2004. How industry is approaching the search for new diagnostic markers and biomarkers. Mol Cell Proteomics $3: 345-354$

Zook DR, Bruins AP. 1997. On cluster ions, ion transmission, and linear dynamic range limitations in electrospray (ionspray) mass spectrometry. Int J Mass Spectrom Ion Processes 162:129-147.

Zybailov B, Coleman MK, Florens L, Washburn MP. 2005. Correlation of relative abundance ratios derived from peptide ion chromatograms and spectrum counting for quantitative proteomic analysis using stable isotope labeling. Anal Chem 77:6218-6224.

Zybailov B, Mosley AL, Sardiu ME, Coleman MK, Florens L, Washburn MP. 2006. Statistical analysis of membrane proteome expression changes in Saccharomyces cerevisiae. J Proteome Res 5:2339-2347.

Zybailov BL, Florens L, Washburn MP. 2007. Quantitative shotgun proteomics using a protease with broad specificity and normalized spectral abundance factors. Mol BioSyst 3:354-360. 
Eva Rodríguez Suárez, PhD is currently a Senior Expert of Mass Spectrometry in CIC bioGUNE, Spain. She obtained her PhD in the Michael Barber Center for Mass Spectrometry (UMIST) in 2006, investigating the role of phosphorylation in leukemogenic cells. Afterwards, she moved to CIC bioGUNE where she was involved in establishing a state of the art mass spectrometry facility for designing and developing qualitative and quantitative mass spectrometric studies in collaboration with biotechnological companies and scientific groups of CICbioGUNE. Her current postdoctoral projects are focused on the application of proteomic strategies to biomedical research.

Professor Anthony D. Whetton is currently the Head of School for Cancer and Enabling Sciences at Manchester University. In cancer research Manchester was the leading university in the UK in the Research Assessment Exercise 2008. He is past Director of the Leukaemia Research Fund Cellular Development Unit and is now Director of the Leukaemia Lymphoma Research Mass Spectrometry Unit based at the Wolfson Molecular Imaging Centre, Christie Hospital. He obtained a PhD in signal transduction research and biophysical chemistry from UMIST followed by a move into the field of experimental haematology, with 2 years postdoctoral research in the laboratory of Professor Michael Dexter. He left this position to take up a lectureship at UMIST in 1984 where he became the Professor of Cell Biology in 1995 and Head of Department in 2001. He then joined the School of Medicine at Manchester University in 2003 as Professor of Cancer Cell Biology, based at the Christie Hospital. Here he established a state of the art biological mass spectrometry facility for stem cell and leukemia research. He is currently systematically defining the downstream proteomic and phosphoproteomic effects of the protein tyrosine kinases associated with myeloproliferative disorders and myeloid leukemias to discover common mechanisms for leukemic transformation. He is also Adjunct Professor in the Department of Gene and Cell Medicine at Mount Sinai School of Medicine in New York, USA where he works with the Black Family Stem Cell Institute, using proteomics to define embryonic stem cell differentiation control. 